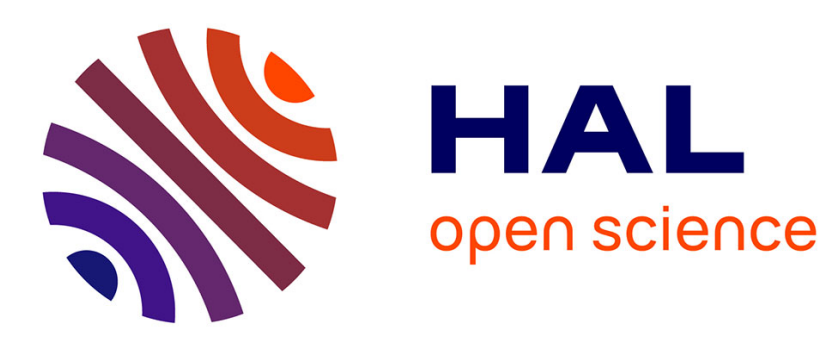

\title{
Structural Insights into TCTP and Its Interactions with Ligands and Proteins
}

\author{
Nadine Assrir, Florian Malard, Ewen Lescop
}

\section{To cite this version:}

Nadine Assrir, Florian Malard, Ewen Lescop. Structural Insights into TCTP and Its Interactions with Ligands and Proteins. TCTP/tpt1 - Remodeling Signaling from Stem Cell to Disease, pp.9-46, 2017, 10.1007/978-3-319-67591-6_2 . hal-02309075

\section{HAL Id: hal-02309075 \\ https://hal.science/hal-02309075}

Submitted on 27 Jul 2021

HAL is a multi-disciplinary open access archive for the deposit and dissemination of scientific research documents, whether they are published or not. The documents may come from teaching and research institutions in France or abroad, or from public or private research centers.
L'archive ouverte pluridisciplinaire HAL, est destinée au dépôt et à la diffusion de documents scientifiques de niveau recherche, publiés ou non, émanant des établissements d'enseignement et de recherche français ou étrangers, des laboratoires publics ou privés. 
« This document is the Accepted Manuscript version of a Published Work that appeared in final form in the book TCTP/tpt1 - Remodeling Signaling from Stem Cell to Disease after technical editing by the publisher. To access the final edited and published work see https://doi.org/10.1007/978-3-319-67591-6_2 " 


\section{Structural insights into TCTP and its interactions with ligands and proteins.}

Nadine Assrir ${ }^{\text {a }}$, Florian Malard ${ }^{\text {a }}$, Ewen Lescop ${ }^{\text {a }}$

a Institut de Chimie des Substances Naturelles, CNRS UPR2301, Université Paris-Sud, Université Paris-Saclay, 1 avenue de la Terrasse, 91190 Gif-sur-Yvette, France.

Abstract: The 19-24 kDa Translationally Controlled Tumor Protein (TCTP) is involved in a wide range of molecular interactions with biological and non-biological partners of various chemical compositions such as proteins, peptides, nucleic acids, carbohydrates or small molecules. TCTP is therefore an important and versatile binding platform. Many of these protein-protein interactions have been validated, albeit only few received an in-depth structural characterization. In this chapter we will focus on the structural analysis of TCTP and we will review the available literature regarding its interaction network from a structural perspective.

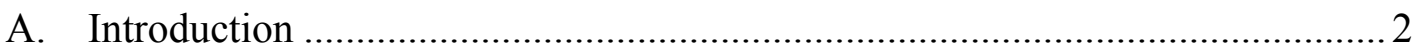

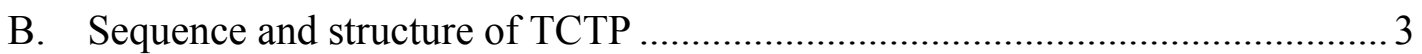

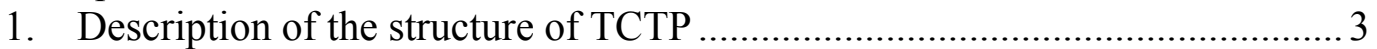

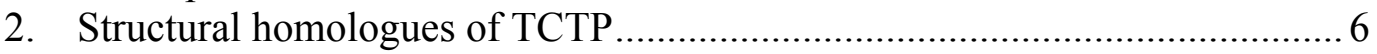

3. Functional elements within TCTP sequence ........................................... 9

C. Binding properties and structural aspects of TCTP in complex with ions, small

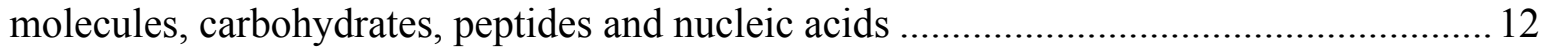

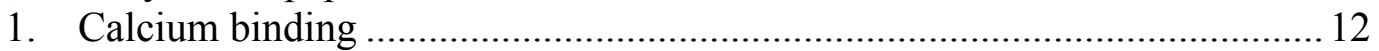

2. Antihistaminic drugs and the related sertraline/thioridazine ........................ 13

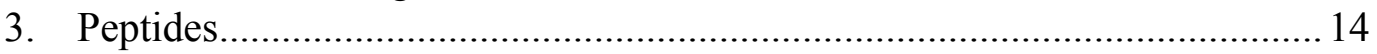

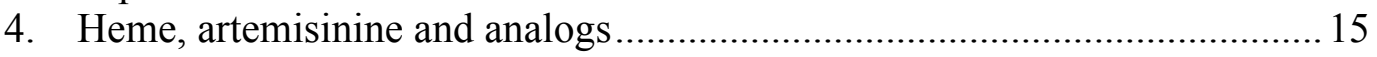

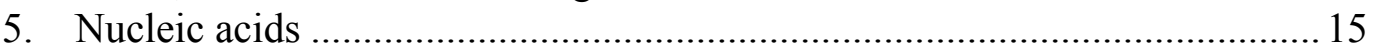

6. Bombyx mori TCTP as a binding platform for saccharides.......................... 16

D. Structural aspects of TCTP in complex with proteins ......................................... 16

1. TCTP directly interacts with dozens of proteins ......................................... 16

2. Structural informations on native complexes .......................................... 17

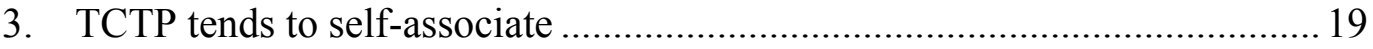

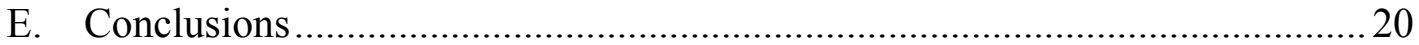

\section{A. Introduction}

This chapter will focus on the structural aspects of TCTP in the context of its wide interaction network, with the aim of being as a comprehensive as possible. First we will describe the available structures of TCTP and compare them with other structurally related proteins. Then in a second part, we will discuss the properties of some amino acid regions of TCTP that are important due to their conservation and/or specific functions. Then the last two parts will describe the large interactome of TCTP involving non-proteic or proteic molecules. Two recent reviews $(1,2)$ also covered part of the topics of this chapter. However the last four years have witnessed astonishing progress in TCTP field and we felt that an updated description of TCTP interactome was necessary. We believe this chapter will be useful not only for the general reader but also for TCTP experts, to overcome the difficulties associated with the multiple names of TCTP found in literature. Indeed, depending on its intra or 
extracellular localization, or on the species, TCTP is also called Histamine-Releasing factor (HRF), p23, p21, Q23, fortilin, Mmilp (yeast) or Tpt1. This confusing nomenclature undoubtedly hinders the diffusion of knowledge on this protein within the community, and hence slows down the progress of its characterization.

\section{B. Sequence and structure of TCTP}

\section{Description of the structure of TCTP}

The high-resolution structures of TCTP from different organisms have been determined by NMR or X-ray crystallography (see Figure 1). These include the malaria parasites Plasmodium falciparum (3) and knowlesi (4), the yeast Schizosaccharomyces pombe (5), the worm Caenorhabditis elegans $(6)$ and wild type $(7,8)$ or E12V mutant (9) human TCTP. The structures of TCTP are highly conserved between different organisms. TCTP is a monomeric protein, although covalent and non-covalent TCTP dimers have been observed, as discussed in paragraph D.3. The TCTP fold contains three $\alpha$-helices $\left(\alpha_{1}, \alpha_{2}, \alpha_{3}\right)$ and eleven $\beta$ strands arranged in two small $\beta$-sheets $\beta_{2}-\beta_{1}-\beta_{11}$ and $\beta_{5}-\beta_{6}$ and a larger $\beta$-sheet $\beta_{7-} \beta_{8}-\beta_{9-}-\beta_{10}-\beta_{4}-\beta_{3}$ (Figure 1A). The two $\beta$-sheets $\beta_{2}-\beta_{1}-\beta_{11}$ and $\beta_{7}-\beta_{8}-\beta_{9}-\beta_{10}-\beta_{4}-\beta_{3}$ are twisted and their relative arrangement forms a $\beta$-tent (10). The helices $\alpha_{2}$ and $\alpha_{3}$ are connected by a short loop that creates a kink to form a helical hairpin. This hairpin sits on one side of the large surface defined by the six-stranded $\beta$-sheet. The different TCTP structures differ by the secondary structure elements that slightly vary in length and relative positioning. For example the $\beta$-sheet $\beta_{2}-\beta_{1}-\beta_{11}$ is severely distorted in $C$. elegans TCTP compared to the other structures. One conserved feature of TCTP structures is the long $~ 30$-33-amino-acid loop connecting strands $\beta_{5}$ and $\beta_{6}$ (between residues T39 and V66 in human TCTP sequence, see sequence alignment in Figure 2). This loop is highly flexible as judged from missing electron density in crystal structures $(3,4,8,9)$ and from the scarcity of long-range NOE restraints in this region leading to poor structural convergence in NMR structures $(5-7)$. The ${ }^{15} \mathrm{~N}$ relaxation NMR study revealed that, in human TCTP, the loop explores a wide conformation range at the pico- to nano-second timescale (7). The $\mathrm{N}$ - and $\mathrm{C}$ - extremities of the loop are more or less rigid and tend to form a short $\beta$-sheet $\beta_{5}-\beta_{6}$ that projects the loop towards the bulk solution and away from the core structure. This is clearly visible in the NMR structures of human and S. pombe TCTP (Figure 1B). The NMR structure ensemble of C. elegans TCTP (Figure 1B) is more compact and the loop explores a more restricted conformational space, suggesting that a few long-range NOE-derived distances bring the loop in relative close proximity to the core TCTP structure. It is therefore possible that this loop may have distinct dynamic properties in the different species. 


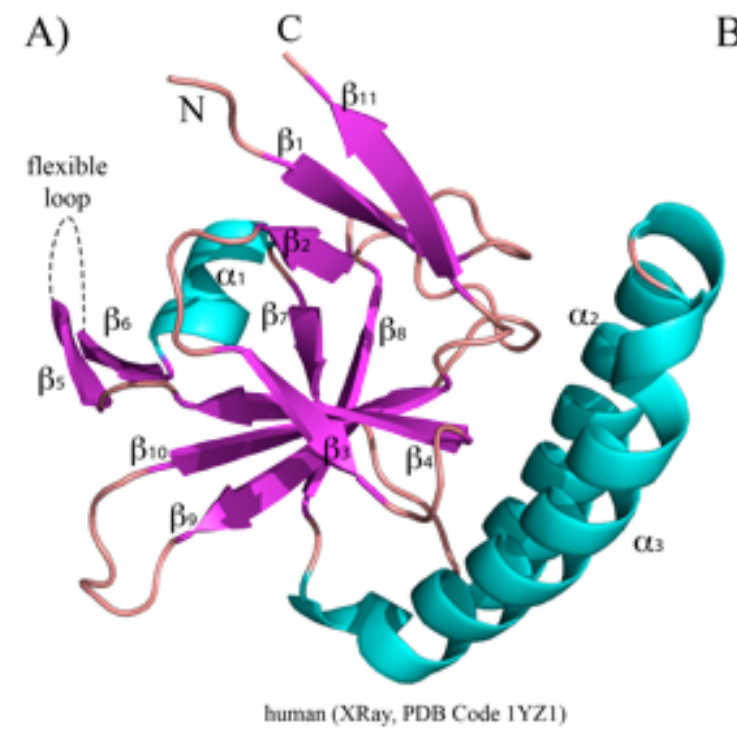

B)

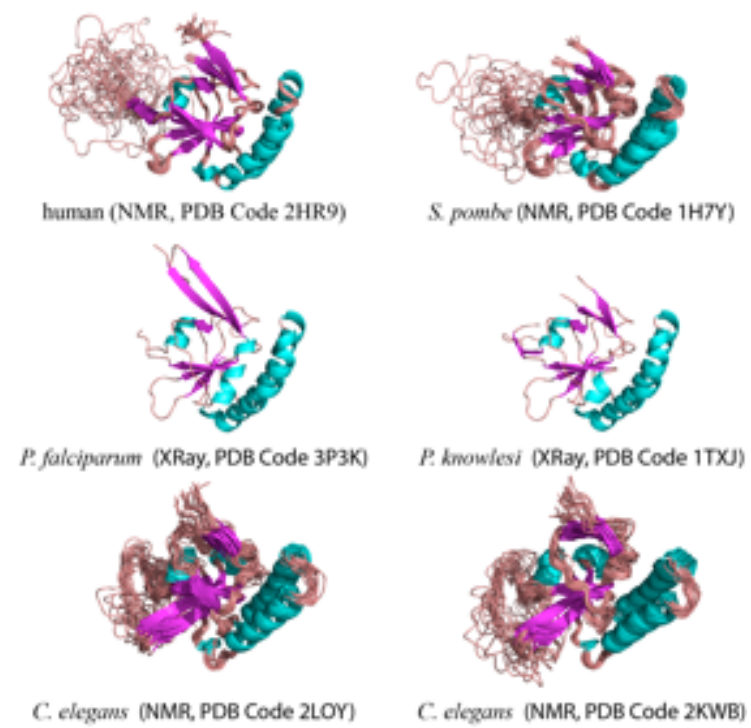

Figure 1 : Ribbon representation of the structures of TCTP from different organisms. (A) Crystal structure of the human TCTP (PDB Code 1YZ1 (8)). The secondary structure elements are shown using the nomenclature from Figure 2 and the $\alpha$-helical, $\beta$-strand and coil regions are colored cyan, magenta and rose, respectively. The 30-33 amino acid long loop between strands $\beta 5$ and $\beta 6$ is not visible in the crystal structure and is indicated as a dotted line. Of note, the length of the dotted line does not represent the effective length of the loop. (B) TCTP structures from human (7), fission yeast Schizosaccharomyces pombe (5), the parasites Plasmodium falciparum (3) and knowlesi (4), and the worm Caenorhabditis elegans (6). For NMR structures, the ensemble of conformations is shown to illustrate the flexibility of the long loop due to the absence or scarcity of experimentally determined long-range distance constraints in this region.

TCTP is a highly charged acidic protein with an isoelectric point around 4.5. Accordingly the 172 amino-acid human TCTP contains up to $31 \mathrm{Asp} / \mathrm{Glu}$ and $20 \mathrm{Lys} / \mathrm{Arg}$ amino acid residues. The vast majority of these charged residues are solvent-exposed at the surface of the protein, making TCTP a highly water-soluble molecule. TCTP is amongst the most abundant proteins in many eukaryotic cells, and the high solubility of TCTP is therefore an important feature. Several charged residues form salt bridges that are partially buried at the surface of the protein. In all TCTP structures, one aspartate residue (D6 in human TCTP sequence) located at the $\mathrm{C}$-terminus of strand $\beta 1$ is significantly buried in a hydrophobic environment where it makes hydrogen bond with the main chain amides of I8 and S9 forming an Asx-turn motif on the loop $\beta 1-\beta 2$. D6 forms an additional $\mathrm{H}$-bond with the amide group of M145 at the N-terminus of strand $\beta_{9}$, and hence, creates contact between the $\beta_{2}-\beta_{1}-\beta_{11}$ and $\beta_{7}-\beta_{8}-\beta_{9}-\beta_{10}-\beta_{4}-\beta_{3} \beta$-sheets that define the $\beta$-tent. Another aspartate (D11), located at the beginning of strand $\beta_{2}$ is also partially buried and form H-bond with the backbone of N139 in the loop $\beta_{8}-\beta_{9}$. Both D6 and D11 are strictly conserved, thus revealing their potential roles in the stabilization of the $\beta$-tent conformation, and consequently of the TCTP fold. 

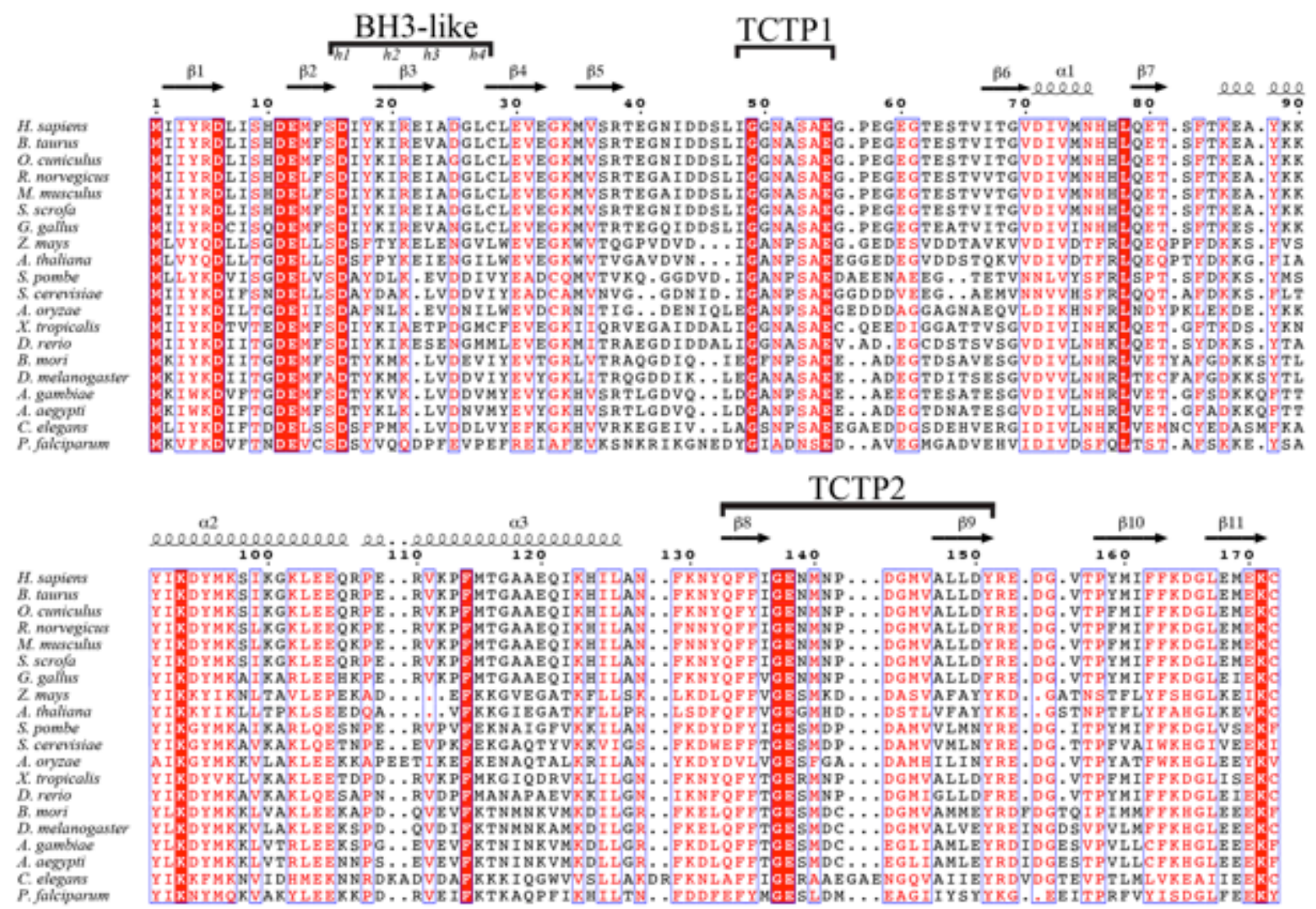

Figure 2: Amino acid alignment of selected TCTP sequences from mammalian, parasites, plants and insects. The amino acid numbering and the secondary structures are from the human sequences (PDB 2HR9) and are shown on the top of the alignment. The picture was prepared using the ESPript webserver (11) with the Blosum62 color scheme. Specific sequences such as TCTP1 and TCTP2 signatures, the BH3-like domain together with the h1, $\mathrm{h} 2$, h3, h4 positions conserved in conventional BH3 domains are highlighted. 


\section{Structural homologues of TCTP}

B)

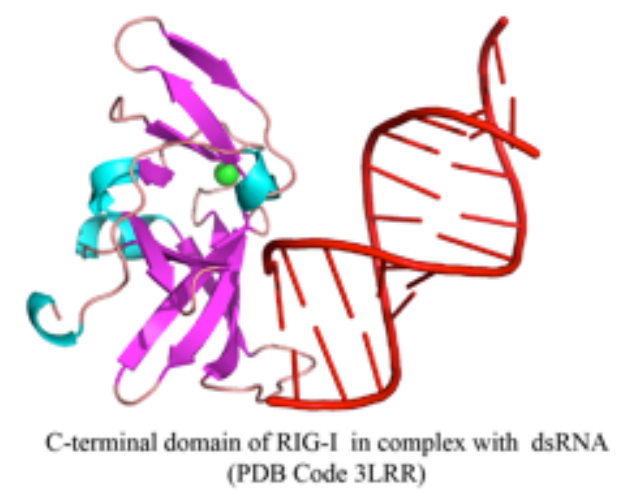

A)

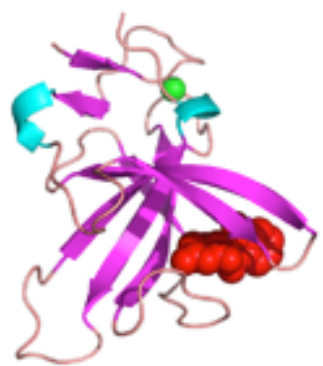

$$
\text { (PDB Code 3LRR) }
$$

Cereblon in complex with thalidomide (PDB Code 4CI1)

C)

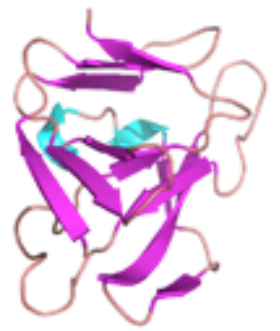

DUF427 (PDB Code 3DJM)

F)

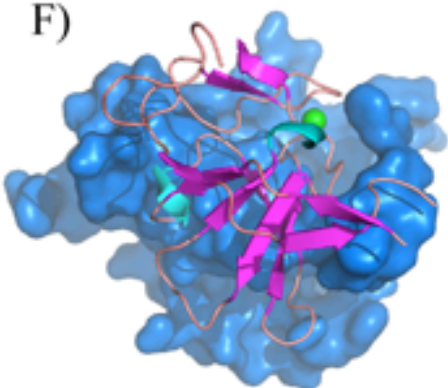

Mss4 in complex with Rab8 (PDB Code 2FU5)
D)

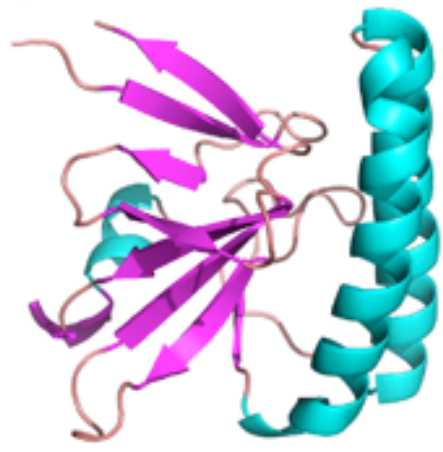

TCTP (PDB Code 1YZ1)
E)

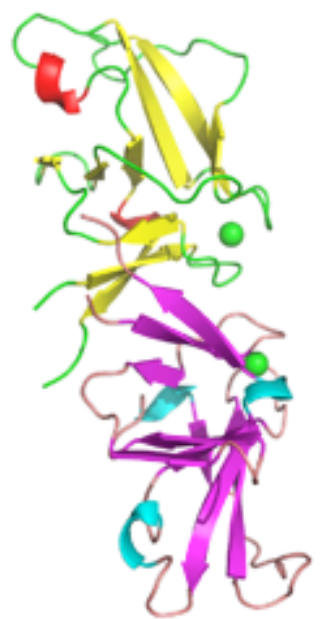

Dimer of Mis 18 (PDB Code SHJ0)

Figure 3 : Comparison of structures showing homology to TCTP: TCTP (PDB code 1YZ1(8)), Cereblon in complex with thalidomide (PDB Code 4CI1 (12)), C-terminal domain of RIG-I in complex with dsRNA (PDB 3LRR (13)), DUF427 (PDB Code 3DJM, unpublished), the dimer of Mis18 (PDB Code 5HJ0 (14)), Mss4 in complex with Rab8 (PDB Code 2FU5, Rab8 protein is shown as a light blue surface (15)) and MsrB in complex with the substrate Ac-Met-R-O-NHMe (PDB Code 3HCI (16)). The structures were superimposed on their common $\beta$-tent fold. The protein ribbons are colored according to the secondary structure elements with the $\alpha$-helical, $\beta$-strand and coil regions colored cyan, magenta and rose, respectively. For the dimeric Mis18, the two monomers are colored with different schemes. When available, zinc ions are represented as green spheres, and ligands are shown in red. 
The long helical hairpin represents a hallmark of TCTP and shares strong structural similarity with other proteins (8). These include transmembrane domains of diphtheria toxin and bacterial colicins as well as the helices H5-H6 found in Bcl2 family proteins, such as Bax (8). However, the similarity is restricted to structural features since there is poor amino acid homology between these proteins. The helical hairpin, and in particular residue K102, plays a role in the anti-apoptotic function of TCTP (8). Bax has a strong pro-apoptotic property and remarkably, replacing the essential helices H5-H6 of Bax by helices $\alpha_{2}$ and $\alpha_{3}$ from TCTP does not change much Bax pro-apoptotic functions suggesting that TCTP helical hairpin can structurally and functionally replace Bax helical hairpin (8).

With the determination of the structure of TCTP, it was also realized that TCTP shares strong structural similarities with the MsrB and Mss4/Dss4 families $(5,17)$ (see Figure 3FG). The methionine-R-sulfoxide reductase $\mathrm{B}(\mathrm{MsrB})$ is an enzyme involved in the protection of cell against oxidation damages by reducing methionine sulfoxide back to methionine. The Mss4/Dss4 proteins bind the GDP/GTP free form of Rab GTPase proteins and act as a poorly efficient guanine nucleotide exchange factor or guanine nucleotide-free chaperon (15). Despite their different functions, the three protein families share a similar topology. Although the length of the $\beta$-strands differs in the different families, they all have in common the two $\beta$ sheets forming the $\beta$-tent. Nevertheless, some clear variations occur. Firstly, the long flexible loop is absent in MsrB and Mss4/Dss4 proteins and is specific to TCTP. Secondly, the MsrB and Mss4/Dss4 families do not possess the long helical hairpin present in TCTP. In the case of Mss4/Dss4 proteins, an additional two-stranded $\beta$-sheet occupies roughly the position where the helical hairpin is located in TCTP structure (see Figure 3DFG). In MsrB, a short helical hairpin is present roughly at the same spatial position as the long helical hairpin of TCTP with respect to the $\beta$-tent, however in MsrB the two helices represent insertions at the $\mathrm{N}$-terminus instead of being inserted between strands $\beta 7-\beta 8$ as in TCTP. The size and the position of the helical hairpin in MsrB allows the positioning of the substrate on the solvent accessible surface of the larger $\beta$-sheet as seen in Figure 3G. The similarity of TCTP and Mss4 folds has prompted studies to explore the role of TCTP in guanine nucleotide exchange. TCTP has found to be a GDP exchange inhibitor in the elongation step of protein synthesis (18). In contrast, it has been proposed to stimulate the GTP/GDP exchange on the Rheb GTPbinding protein to control mTORC1-dependent cell growth and proliferation $(9,19)$, although this function has been challenged $(20,21)$.

The Protein DataBank was recently interrogated for structural similarities $(2,10)$ and several new TCTP structural homologues were identified, although the proteins shared very little sequence homology: Cereblon, Mis18, RIG-I, and DUF427 (Figure 3). Because structural similarities could reveal hints about yet unknown TCTP function, we will describe those proteins from a structural but also interactome perspective.

Cereblon $(\mathrm{CRBN})$ is a multidomain protein that interacts with the damaged DNA binding protein 1 (DDB1) and forms one component of the CUL4-RBX1-DDB1-CRBN E3 ubiquitin ligase complex to regulate the selective proteolysis of key proteins in DNA repair, replication and transcription (22). The N-terminal extremity of Cereblon contains the LON protease domain and the DDB1-binding region whereas the C-terminal extremity contains the CULT domain (Cereblon domain of Unknown activity, binding cellular Ligands and Thalidomide, (10)) that shows structural homology to TCTP. Cereblon has been identified as the primary teratogenic target of the well-known thalidomide drug (23) and the thalidomidebinding region is located in the CULT domain (12) (see Figure 3A). The binding of the immunomodulatory (IMiD) agents such as thalidomide to Cereblon inhibits ubiquitination of 
the CUL4-RBX1-DDB1-CRBN E3 ubiquitin ligase substrates and redirects the enzyme towards new protein targets such as the ikaros family of transcription factors IKZF1 and IKZF3 (12) or casein kinase $1 \alpha(\mathrm{CK} 1 \alpha)(24)$. This IMiD-induced reprogramming of CUL4RBX1-DDB1-CRBN E3 ubiquitin ligase relies on novel interactions at the surface of the IMiD-CULT domain complex (25) that allows new substrate recognition such as CK1 $\alpha$. Cereblon is involved in several protein-protein interactions including $\mathrm{BKCa}, \mathrm{ClC}-2, \mathrm{AMPK}$, PSMB4, ikaros and aiolos (IKZF3) and MEIS2 as well as with Ago2 (26).

The protein Mis18 is a component of the kinetochore, an essential actor in centromere localization. In S. pombe, Mis18 acts as an obligatory homodimeric form mediated by the Nterminal Yippee-like domain, that adopts a $\beta$-tent conformation (14) (see Figure 3E). The interface of the dimer is stabilized by strong interactions between the three-stranded $\beta$-sheets of the two protomers. An additional $\alpha$-helix at the C-terminus is involved in tetramerization (not visible). In human Mis18, oligomerization is conserved but involves an heterodimer formed between two Mis18 isoforms, Mis18 $\alpha$ and Mis $18 \beta$ that share 29\% identity (14). Within the Mis18 complex, the Mis18 $\alpha$ and Mis18 $\beta$ have evolved to different functions. Mis18 $\alpha$ interacts with the Mis18 Binding Protein 1 (Mis18BP1) through its Yippee-like domain whereas Mis18 $\beta$ interacts with the $\mathrm{C}$ terminus of CENP-C also through its Yippeelike domain. (27). The conserved substrate-binding pocket in Mis18 is required for its function although the partners are not known exactly (14).

The retinoic acid-inducible gene I (RIG-I) and its homologs MDA5 and LGP2 of the RIG-I like receptors (RLR) family recognize replicating viral RNA for the innate anti-viral immune response. They possess a helicase domain followed by a C-terminal conserved Yippee-like domain responsible for the binding specificity to double strand and 5'triphosphated single strand RNA. RNA binding induces a major conformational change that releases RLR autoinhibition and results in the activation of type I interferon for the control of viral infection $(28,29)$. The C-terminal region that shows homology to TCTP contributes to RNA recognition through a positively charged groove formed by the large $\beta$-sheet and involves interactions essentially with strands $\beta_{7-} \beta_{8}-\beta_{9}-\beta_{10}-\beta_{4}-\beta_{3}(13,30)$ (see Figure 3B).

The DUF427 protein also belongs to the same structural family as judged from its 3D structure (see Figure 3C). The function of this protein is currently unknown. As proposed before (10), the glutathione-dependent formaldehyde-activating enzyme (GFA) that catalyzes the formation of S-hydroxymethylglutathione from formaldehyde and glutathione also shares some structural similarities with the abovementioned proteins. We did not include this enzyme in the analysis because the similarities are restricted to a structural subdomain.

One common feature of a subset of proteins from the $\beta$-tent family is to bind a zinc $\left(\mathrm{Zn}^{2+}\right)$ ion at the apex of the $\beta$-tent. This zinc ion is present in Mis18, Cereblon, RIG-I and MSS4 and is coordinated by two conserved CXXC motifs. It has been demonstrated that zinc binding is essential for RIG-I in vivo (30) and the zinc binding site may contribute to stabilize the two $\beta$-sheets forming the $\beta$-tent. In contrast, the cysteines required for zinc binding are largely absent in TCTP and DUF427, and most often are lacking in MsrB. Accordingly, zinc binding has not been reported for these proteins. Consequently, zinc likely does not play any substantial role for these proteins. Alternative processes therefore stabilize the $\beta$-tent fold in proteins lacking the zinc-binding site. We proposed that the conserved aspartates D6/D11 could contribute to the TCTP fold (vide supra). 
Proteins from the $\beta$-tent fold family share no detectable sequence homology and have very distinct biological activities and functions. They bind a wide spectrum of compounds ranging from small molecules to nucleic acids and proteins. As noted in a recent survey (10), Cereblon, RIG-I and MsrB bind partners (small molecules or RNA) through the solventexposed large $\mathrm{C}$-terminal $\beta$-sheet. This is clearly illustrated in Figure 3 that shows the similar positioning of the ligands (shown in red) sitting on the same face of the large $\beta$-sheet. It is likely that the $\beta$-tent conformation has converged to expose this binding surface. In TCTP, the binding position is occupied by the helix hairpin, which reinforces the versatility of the $\mathrm{C}$ terminal $\beta$-sheet to bind various molecular types, including internal peptide resulting from gene evolution. The presence of the helical hairpin in TCTP clearly hampers binding of TCTP ligands on the $\mathrm{C}$-terminal $\beta$-sheet but at the same time, provides a novel surface formed by the helix hairpin. As shown in Figure 3, other proteins adopting the $\beta$-tent fold expose other interfaces for interaction. In Mis18, homo- or heterodimerization occur through the smaller $\beta$ sheet. Another example of the versatility of the $\beta$-tent to expose binding surface is provided by the structure of the Mss4/Rab8 complex. In this structure, the stretch encompassing helix $\alpha 1$ and the following strand $\beta 7$ from Mss 4 is largely involved in the interaction with Rab8. Taken together, these proteins most likely result from a convergent process to adopt the $\beta$-tent fold that can accommodate various binding modes and binding partners. Not surprisingly, structural elements that represent extensions when compared to the minimal fold also occupy known binding interface. This is for example illustrated by the helical hairpin of TCTP and the long insertion between strands $\beta_{3}$ and $\beta_{4}$ in Mss 4 that both interact with the C-terminal $\beta$ sheet. Taken together, TCTP belongs to a large structural family that exposes different binding surfaces and has the ability to interact with molecules of various types. Due to this diversity, it is difficult to predict the interactome and the function for members from this family on the sole basis of the fold.

\section{Functional elements within TCTP sequence}

\section{a) Conserved signatures}

TCTP amino acid sequences are highly conserved across eukaryotic cells, including in animal and plant kingdom, as well as in yeast (31) (Figure 2). TCTP homologues have also been detected in spider venom, C. elegans or various parasites. Two primary regions of high sequence homology were identified and termed TCTP1 and TCTP2 signatures (5). TCTP1 is an eight amino acid sequence (consensus sequence IG[A-G]N[A-P]SAE) located between residues 48 and 55 in the flexible loop (we use here by default human TCTP numbering, see Figure 2) and is largely hydrophilic. Because this region is not involved in the stabilization of the overall fold of the protein, its conservation is most likely related to functional constraints, such as protein-protein interaction or post-translational modifications. The residue S53 is a predicted phosphorylation site for PI3KK kinase and its phosphorylation was observed in human cell line during mitosis $(32)$, but not confirmed in two other studies $(33,34)$. The conservation of S53 in TCTP1 signature might therefore be related to TCTP regulation. The TCTP2 signature is located between residues 133 and 151 and largely conserved residues are: F134-F135 in strand $\beta 8$, G137-E138-M140-D143 in the following $\beta 7-\beta 8$ loop, and Y151 at the C-terminal extremity of strand $\beta 9$. Many of these residues are solvent-exposed and do not contribute significantly to the 3D TCTP fold, suggesting that their conservation reveals nonstructural evolutionary pressure. Beyond TCTP1 and TCTP2, other residues are extremely well conserved in TCTP, including D6, D11, E12, D16, L78, K93, F114, V156 and K171. D6 
and D11 have already been discussed. E12 has been shown to be essential for protein-protein interaction $(9,19,35)$ and for TCTP guanine nucleotide exchange (GEF) activity $(9,19)$. The conserved solvent exposed residue K93 in helix $\alpha 2$ is involved in protein-protein interaction (36).

\section{b) Functional motifs in TCTP}

\section{TCTP contains a non-canonical cell-penetrating peptide}

TCTP is able to spontaneously penetrate cells of various types but also multiple organs (37). This property is associated to a protein transduction domain (PTD) corresponding to the first ten residues of human TCTP (MIIYRDLISH) (37). The internalization seems to involve lipid raft-mediated endocytosis and macropinocytosis $(37,38)$. The mechanism is not yet understood and seemingly differs from other known protein transduction domain, in the sense that it does not involve recognition by the cell surface heparin-sulfate (37). TCTP-PTD has been advantageously used as a cargo for the internalization of fused peptide or proteins with potential in drug delivery (39-41). Nevertheless the biological meaning of the cell-penetrating property of TCTP is not yet clarified. A recent study pointed out that extracellular TCTP is sufficient to reprogram intracellular signaling pathways to promote migration and invasiveness in colorectal cancer cells (42), which strongly supports the idea that TCTP cell penetration may play (patho)physiological roles. In these processes, TCTP import may mirror the exosome-mediated TCTP export process for cell-to-cell communication (43). From a structural perspective, the PTD domain encompasses the first strand $\beta_{1}$ and the following loop $\beta_{1}-\beta_{2}$ that form the central part of the smaller $\beta$-sheet. In TCTP structure, most of the side chains of the PTD are accessible for interaction at the surface. However the 3D conformation of the peptide seems not to be required for cell penetration since the 10-mer TCTP-PTD peptide can efficiently transport various molecules, although it probably lacks stable 3D conformation. Hence it is not clear whether TCTP remains folded or undergoes severe unfolding during cell internalization.

\section{TCTP contains a non-canonical BH3-like domain}

The anti-apoptotic Bcl-xL protein is a partner of TCTP and the N-terminal fifty residues of TCTP were identified to contribute to TCTP/Bcl-xL interaction (44). An in-depth sequence comparison with classical $\mathrm{BH} 3$ domains, that are known Bcl-xL ligands, revealed that TCTP contains a BH3-like domain between residues 16 and 27 (45). BH3 domains usually fold as an $\alpha$-helix in protein-protein complexes and are characterized by highly conserved residues at positions $\mathrm{h} 1, \mathrm{~h} 2, \mathrm{~h} 3$ and $\mathrm{h} 4$ that line on one face of the $\alpha$-helix and that contribute to stabilize the helix in the BH3-binding groove of the partners, such as Bcl-xL. Compared to classical BH3 domains, the TCTP BH3-like domain contains the conserved residues I20, I23 and L27 at h2, h3, and h4 positions respectively but lacks the hydrophobic residue commonly found at h1 position in BH3 domains (see Figure 2). In TCTP, the h1 position is occupied by the strictly conserved D16. Accordingly, the structure of Bcl-xL in complex with a peptide derived from $\mathrm{TCTP}_{11-31}$ sequence showed that residues 16-27 of TCTP folds into a $\alpha$-helix that occupies the classical BH3 binding groove of Bcl-xL (45). Surprisingly, instead of decreasing the anti-apoptotic activity of Bcl-xL, as would be expected from competition of TCTP BH3-like domains with canonical BH3 domains at the same binding groove on Bcl-xL, TCTP appears to potentiate the anti-apoptotic activity of Bcl-xL through a yet unknown mechanism (45). Whether TCTP BH3-like domain acts also on other $\mathrm{BH} 3$ binding proteins, such as Mcl-1, remains to be investigated. 
TCTP interacts with the actin cytoskeleton (46). The comparison of the primary sequences of TCTP and of ADF/cofilin, a family of actin-binding proteins that destabilize actin filaments, unveiled a region of high sequence homology (47). Indeed, the stretch of residues G69 to E105 that encompasses the helices $\alpha 1$ and $\alpha 2$ and the intervening strand $\beta 7$, shows significant conservation with the G-actin binding site of cofilin (47). Accordingly, TCTP preferentially binds to the globular actin (G-actin) than to filamentous actin (F-actin), but TCTP binding does not alter actin dynamics (47).

\section{c) Post-translational modifications of TCTP}

Several post-translational modifications are predicted on mammalian TCTP. The ELM server (48) (http://elm.eu.org) predicts for TCTP solvent exposed regions the following modifications: cleavage sites for caspases 3 and 7, glycosaminoglycan or N-glycosylation attachment site (S53), CK2 phosphorylation sites (residues S9, S37) or Polo-like kinase-1 (Plk1) phosphorylation sites (S46, S64, T65 and S82). Experimentally, only a few posttranslational modifications have been observed.

Biologically important phosphorylations occur at residues S46 and S64. In vivo, the polo-like kinase Plk1 phosphorylates these two serines to detach TCTP from the mitotic spindle for proper mitosis (49). The Plk1-dependent phosphorylation of TCTP contributes to the subcellular localization of TCTP (49-51). S46 phosphorylation has been proposed to be a biomarker of Plk1 level and kinase activity, with potential interest in anti-tumor drug design strategy targeting Plk1 (50) and is observed in mitotic cells (32). In vitro, the activated Plk1 can phosphorylate TCTP at position S46 but not at position S64 (52). It has been proposed a hierarchical mechanism by which S64 phosphorylation occurs only when S46 is already phosphorylated (49). The serine S46 is conserved in higher eukaryotes whereas S64 is only partially conserved (conserved in mammalian but not in chicken sequences for example, see Figure 2A). Therefore the impact of S46/S64 phosphorylations is limited to higher eukaryotes (52). Mutations of serines 46 or 64 to glutamate residues abrogate TCTP binding to MDM2 and to the drugs sertraline and thioridazine (53). Considering these mutations mimic phosphoserines, it might indicate that TCTP phosphorylation could also perturb TCTP interactome. Furthermore, it has been proposed that phosphorylated TCTP could be a target of dihydroartemisinin in cancer cells (51). More recently, the insulin-dependent phosphorylation of S9 and S15 has been reported (33), albeit with yet unknown functional consequences. T39 and S53 phosphorylation have also been observed in mitotic human cell (32). Phosphorylation of TCTP at definite sites is therefore prone to play important roles in TCTP function.

Beyond phosphorylation, the N-glycosylation of TCTP has been reported (54). The attachment site is not known but S53 is a serious candidate, as judged from ELM predictions. The BioGrid server (http://thebiogrid.org) report several proteomics studies indicating that TCTP can be ubiquitinated or sumoylated. The Ubc9-mediated sumoylation of TCTP controls its subcellular localization and the residue K164 was identified as a SUMO-1 substrate (55). The ubiquitination sites are not precisely known, although K19 and K112 could be potentially ubiquitinated (56).

TCTP is known as IgE-dependent histamine-releasing factor (HRF) when it acts in the extracellular space during the human allergic response. The cytokine-like activity of TCTP seems to correlate with extensive post-translational modifications that may include proteolytic 
cleavage, dimerization or oxidation (57). According to the group of Lee (57), dimerization is the dominant process that activates TCTP for its extracellular cytokine-like function. TCTP contains two cysteine residues $\mathrm{C} 28 / \mathrm{C} 172$, of which $\mathrm{C} 172$ seems more important for dimerization (58). This can be rationalized by the fact that residue $\mathrm{C} 28$ is located at the beginning of strand $\beta 4$ and its side chain is completely buried, and in contrast the C-terminal C172 is largely solvent accessible and available for self-association (58). Dimers were also observed in the C172S mutant suggesting that intermolecular C28-mediated disulfide bridge also exists (58). Dimerization as a post-translational modification might be required for TCTP recognition by its receptor during allergy (58). To date, there is no report of the intracellular existence of such covalent dimer, suggesting that the formation of covalent dimer would be specific of the extracellular function of TCTP. Obviously, the different redox potentials in the intra- and extra-cellular environments might control the formation of such dimers.

\section{Binding properties and structural aspects of TCTP in complex with ions, small molecules, carbohydrates, peptides and nucleic acids}

Since its discovery, the number of TCTP ligands has continuously increased. TCTP has the ability to interact with ions, small molecules, carbohydrates, nucleic acids and proteins for its biological functions and several small molecules or peptides have been designed to interfere with TCTP-based cellular processes. In this part, we will introduce the different TCTP non-proteic ligands (see Table 1).

\section{Calcium binding}

Calcium $\left(\mathrm{Ca}^{2+}\right)$ is one of the first molecules shown to interact with TCTP. The first evidence of calcium binding came in 1992 on the TCTP from Trypanosoma brucei parasite (59) and was further extended to other species such as in Wuchereria bancrofti (60), Brugia malayi (60), Schistosoma mansoni (61), rat (62) and human $(63,64)$. Nevertheless $\mathrm{Ca}^{2+}$ binding is not conserved across the phyla since TCTP from ixodid ticks (65) and shrimp (66) do not bind calcium. The functional relevance of calcium binding to TCTP is not well understood. It has been proposed that TCTP may act as a calcium scavenger in the cytosol to protect cells against $\mathrm{Ca}^{2+}$-dependent apoptosis (67). Accordingly, cells expressing TCTP mutant lacking the ability to bind calcium become more sensitive to thapsigargin-triggered apoptosis (67). Following this idea, the anti-apoptotic role of TCTP could be due to multiple mechanisms including the direct interaction with anti-apoptoptic proteins (including Bcl-xL and $\mathrm{Mcl}-1)$ to control their activity but also by preventing the $\mathrm{Ca}^{2+}$-induced permeabilization of the mitochondrial membrane, and the resulting release of pro-apoptotic molecules. The sequestering effect for calcium led recently to the hypothesis of a "buffer-like" role for TCTP to regulate cellular homeostasis by avoiding the unwanted excess of soluble ligands (68). The interplay between TCTP and calcium is reinforced by the observation that calcium regulates TCTP at the transcriptional and post-transcriptional levels (69).

The binding of calcium was studied by different techniques that gave somehow inconsistent conclusions. In one study (67), two rather high-affinity ( $\sim 10 \mu \mathrm{M}$ range) and one lower-affinity binding modes were detected. In contrast, recent NMR (7) and fluorescence (68) studies detected low-affinity binding modes (mM range) but not the high-affinity binding modes, although both techniques are sensitive over an extreme wide range of affinity. The apparent discrepancy could be due to different purification protocols or binding conditions. From a structural perspective, the double mutant (E58A/E60A) looses the ability to bind 
calcium with high affinity (67), indicating that these residues that are located in the long loop are crucial for the interaction. The same study revealed that calcium binding was accompanied by a change in the secondary structure of the protein, as judged from circular dichroism (CD) (67). In the NMR study (7), the calcium binding site was mapped to a region of the protein involving the C-terminal extremities of helix $\alpha 3$ and of strand $\beta 9$ and the loop between strand $\beta 9$ and helix $\alpha 2$. The oxygens from the side chains of residues N131, Q133, and D150 were proposed to coordinate $\mathrm{Ca}^{2+}$. The chemical shift and intensity changes upon calcium binding was rather limited in amplitude and localized to a few amino acid residues. This suggests that TCTP conformation and oligomeric state is well conserved upon $\mathrm{Ca}^{2+}$ interaction, thus corroborating another CD study (68) in which no secondary structure nor oligomeric change was observed up to $50 \mathrm{mM}$ calcium concentration. Calcium triggers monomerization of hemin-induced dimerization (68), possibly through direct competition against hemin binding. Indeed hemin and calcium seems to share a similar binding area on TCTP (68). In their study, Lucas et al. also observed that the presence of calcium contributes to destabilize TCTP by reducing the urea concentration required for denaturation (68).
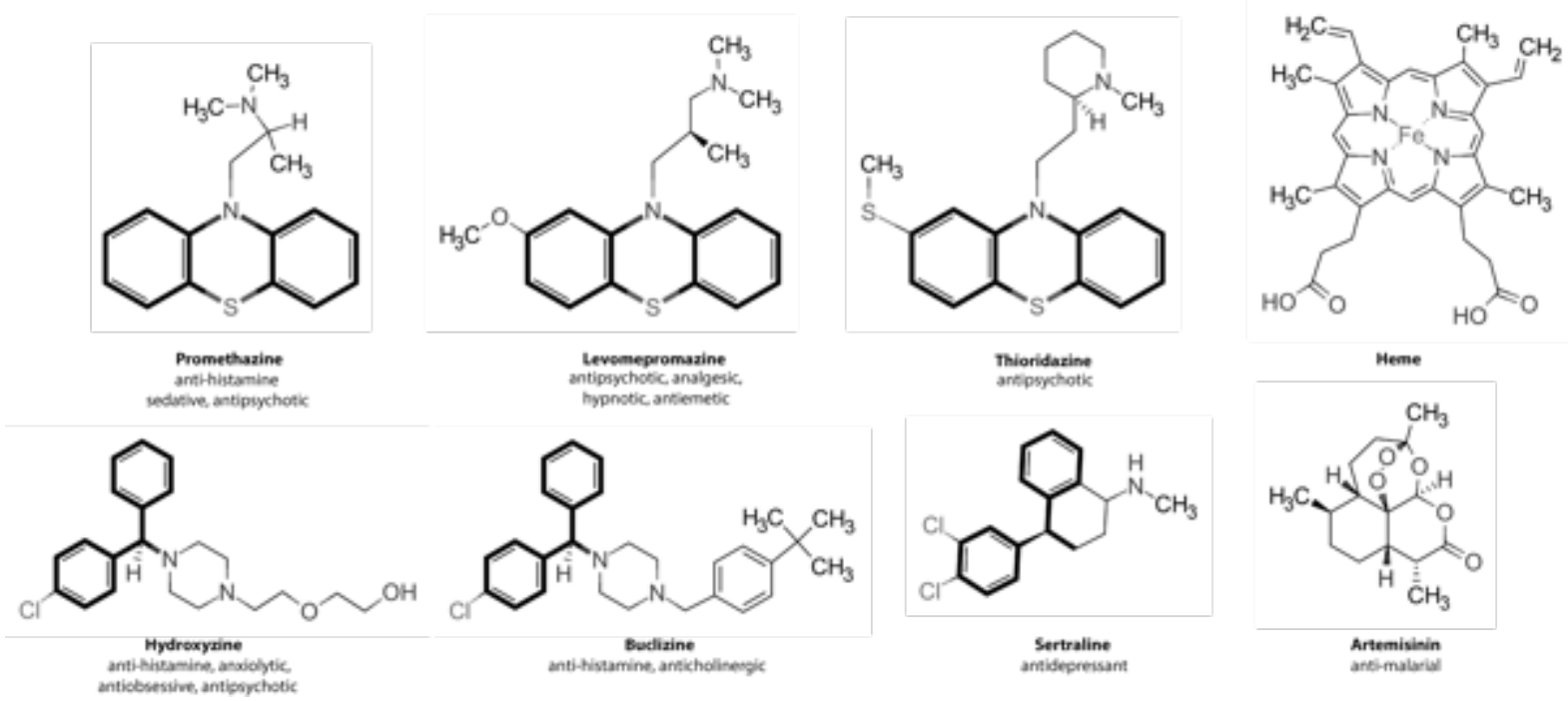

Figure 4 : Structures of small molecules discussed in the manuscript. When available, the biological effects of the molecules are reported. We note that several of these molecules are chiral and often found commercially as racemic mixtures.

\section{Anti-histaminic drugs and the related sertraline/thioridazine}

Any compound leading to reduced TCTP levels in vivo may have potential antitumor activity. Accordingly, because TCTP is a histamine releasing factor, the group of R. Amson and A. Telerman hypothesized that anti-histaminic drugs inhibiting the histaminic pathway were interesting candidates in anticancer strategies (70). This approach was successful and a few antihistaminic compounds such as hydroxyzine and promethazine (see Figure 4) proved efficient to kill tumor cells and to decrease the level of TCTP either directly of indirectly (70). Even greater anti-tumor activity was reported for the structurally related thioridazine and sertraline (see Figure 4) although they do not display anti-histaminic properties $(53,70)$. The drugs thioridazine and sertraline are used for their anti-psychotic and anti-depressive activities, respectively. The direct interactions of sertraline and thioridazine with TCTP have been confirmed by surface plasmon resonance (SPR) (53) and dissociation constant (Kd) of $47 \mu \mathrm{M}$ and $34 \mu \mathrm{M}$ were estimated for sertraline and thioridazine, respectively. The interaction was 
later confirmed for sertraline by thermal shift assays (71). Surprisingly, whereas ligand binding usually stabilizes proteins, sertraline has a destabilizing effect on TCTP by reducing its melting temperature. Both thioridazine and sertraline disrupt the TCTP/MDM2 interaction in vitro which provides a rationale for the restored levels of p53 in cells treated with these pharmacological compounds (53).

To date, the structural information on TCTP / ligands complexes is very limited. Two TCTP mutants (S46E and S64E) loose their ability to bind sertraline and thioridazine (53), suggesting that the residues S46 and S64 are involved in the interaction with the drugs. Accordingly, the TCTP/MDM2 complex is not sensitive anymore to treatments with the drugs (53). As already discussed, residues S46 and S64 are located in the long inserted flexible loop. However whether these residues are directly or indirectly involved in the interaction surface with ligands remains an open question. Additional high-resolution structural information is still awaited to better characterize TCTP / ligand complexes. Interestingly, because these S$>\mathrm{E}$ mutants can be seen as phosphoserine mimics, it is possible that Plk1-mediated phosphorylation perturbs TCTP/ligands interaction. Drug design programs targeting TCTP should therefore take into account the potential distinct binding properties of the molecules to phosphorylated and unphosphorylated TCTP in order to inhibit the proper TCTP forms in vivo.

A recent in silico docking study (72) provided new insights into the molecular interaction of TCTP with twelve anti-histaminic compounds. The binding of levomepromazine or buclizine (see Figure 4) was confirmed in vitro by microscale thermophoresis giving dissociation constants of $57 \mu \mathrm{M}$ and $430 \mu \mathrm{M}$ respectively (72). All tested ligands (except cetirizine) were found to dock onto TCTP at the same position, in an area of the loop encompassing the stretches T39-I48 and E60-T65 that contains both S46 and S64, thus confirming that these two serines could be binding hotspots in TCTP (72). However the simulation was carried out on a single conformation of TCTP and loop flexibility and the potential conformation change of the loop upon binding were not taken into account. Therefore the binding site derived from this study remain to be confirmed.

\section{Peptides}

TCTP is now an established pharmacological target in cancer- or allergy-related diseases and hence different groups are making efforts to develop peptide-based TCTP inhibitors to interfere with the protein-protein interactions network of TCTP $(73,74)$.

In their study (74), Kadioglu and Efferth carried out an in silico screening of peptide libraries and selected octamer peptides with predicted high affinity. The peptide sequences were rather similar with a consensus sequence WGQWPYHX, where the last residue $\mathrm{X}$ is the only difference between the different peptides. In spite of the small sequence difference, the docking poses of the different peptides segregated into two families differing by the binding groove. One groove is defined by the bottom of the long flexible loop and strands $\beta 7, \beta 8$ and $\beta 9$ on one side of the larger $\beta$-sheet whereas the other groove is located on the other side of large $\beta$-sheet and includes the C-terminus of helix $\alpha 3$. Although the binding with TCTP was not confirmed in vitro, one peptide WGQWPYHC induced specific cytotoxicity against tumor cells in a TCTP-dependent manner without affecting normal cells (74).

In another study (73), the dimeric TCTP was targeted. The covalent dimer is thought to be the active TCTP state in inflammatory processes. With the aim to inhibit TCTP in chronic allergic diseases, three peptides dTBP1 / dTBP2 / dTBP3 were isolated by screening a phage-displayed 7-mer peptide library. Peptides dTBP2 (WYVYPSM) and dTBP3 
(WEFPGWM) were shown to interact with TCTP and with the $\mathrm{TCTP}_{84-108}$ peptide corresponding to the helix $\alpha 2$ in TCTP. The interaction with dTBP2 was demonstrated to be specific to the dimeric versus the monomeric TCTP, and dTBP2 inhibited the cytokine-like effect of TCTP (73). Although they have been designed for different applications and obtained by unrelated approaches, the peptides dTBP1/dTBP2 (73) and WGQWPYHC (74) show striking similarities: they start by a tryptophan residue and tend to contain an aromatic residue at positions 3 or 4 and a proline residue at positions 4 or 5 . However whether all these peptides share the same binding modes remain to be investigated.

\section{Heme, artemisinine and analogs}

P. falciparum TCTP (PfTCTP) is found to be one target of the antimalarial drug artemisinin $(75,76)$ and forms complexes with artemisinin and its metabolites. Covalent, but also non-covalent and reversible complexes have been reported $(3,77,78)$. The artemisininmediated alkylation of TCTP is facilitated by the presence of hemin in particular in a reducing environment (77-79). To date, the exact residues of PfTCTP involved in alkylation are not identified but could be mapped within three peptidic fragments of PfTCTP (3). A more recent study showed that multiple amino acid at the N-terminus can be modified by a reactive artemisinin analog and that $\mathrm{C} 19$ and F19 are key residues for the interaction (80). The reaction is thought to occur through the naturally rare endoperoxide bridge (1,2,4-trioxane structure) that becomes activated by ferrous iron, such as heme, to generate free radicals. The direct binding of heme with human TCTP has been also demonstrated (68) and involves the dyad H76-H77. It was proposed that hemin and calcium shares a common binding pattern on TCTP (68), and accordingly, competes with each other. Upon complex formation with heme, TCTP forms dimers, which can be easily disrupted by calcium (68). Therefore ligand binding is prone to conduct to oligomers of TCTP. In P. falciparum, heme/TCTP interaction could be important for the fate of artemisinin in the parasite. Indeed, TCTP are associated with the parasite food vacuoles that are rich in hemin, as a product of degradation of hemoglobin by the intraerythrocytic parasite (81-83). However it is yet not fully demonstrated if such mechanism can explained the antimalarial mode of action of artemisinin.

The observation of the heme-assisted artemisinin-alkylated TCTP could potentially affect the various TCTP-related functions. Artemisinin can be effective in cancer $(84,85)$ and it has been proposed that artemisinin could adopt a similar mode of action in human cells as in parasites. Interestingly, dihydroartemisinin, a metabolite of artemisinin, binds human TCTP in vitro $(\mathrm{Kd}$ of $38 \mu \mathrm{M})$ and reduces TCTP half-like in a proteasome-dependent manner by increasing its ubiquitination (86). Furthermore an artemisinin analog targets human TCTP in HeLa cancer cells (79) suggesting that artemisinin might covalently interact with TCTP from different organisms. PfTCTP shares $35 \%$ sequence identity with human TCTP and the structures of the two proteins are very similar (3). Therefore a deeper characterization of the interaction of artemisinin with TCTP and its derivatives would be helpful for a better understanding of its antimalarial activity, which is still largely unknown (87), but also of the role of TCTP in cancer biology.

\section{Nucleic acids}

TCTP has been isolated from a search for proteins binding to the mouse oct 4 promoter region using radioactively labeled DNA incubated in Xenopus oocyte extract. The direct interaction between TCTP and the steroidogenic factor-1 (Sf1) site of oct4 promoter was demonstrated in vivo from two independent studies carried out in Xenopus (88) and in mouse pluripotent cells (89). The first 60 amino acid of TCTP appear to be sufficient for Sf1 binding (89). Three studies assessed the function of TCTP as a transcription factor with diverse 
outputs (88-90). In one study carried out in Xenopus (88), the transcription of a subset of genes including oct 4 was activated by TCTP. In their study, Johansson et al. (90) did not observe a change in oct 4 transcription upon shRNA knockdown of TCTP but observed that TCTP interacts with Oct4 protein in vivo. They proposed a mechanism in which TCTP controls oct 4 transcription by perturbing the self-regulatory transcriptional properties of the Oct4 transcription factor. The third study (89) confirmed the binding of TCTP to the Sf1 site of oct 4 promoter in vivo, but demonstrated that DNA binding of TCTP negatively regulated the expression of Oct4 in mouse pluripotent cells. They proposed that different epigenetic modifications in amphibian oocytes and mammalian cells could explain the conflicting results. We retain from these works that TCTP has also the ability to act as a transcription factor, although the direct interaction between TCTP and DNA has to be confirmed in vitro.

TCTP has been captured in a systematic approach targeting RNA binding proteins in HeLa cells (91). In this study, a "zero-distance" strategy was used to select direct contacts between proteins and RNA and to avoid protein-protein crosslinks. This work therefore suggests that TCTP has also the ability to directly bind RNA in cellulo (91).

\section{Bombyx mori TCTP as a binding platform for saccharides}

In the silkworm Bombyx mori, BmTCTP is produced in intestinal epithelial cells and is released into the hemolymph and gut lumen in response to oral microbial infection (92). A study exploring the interaction of BmTCTP with a range of pathogen-associated molecular patterns (PAMP) revealed the broad binding spectrum of BmTCTP (92). BmTCTP interacts with chitin, a polymer formed of $N$-acetylglucosamine, and mixtures of $E$. coli lipopolysaccharides (LPS) or of B. subtilis peptidoglycans (PG). The binding of TCTP with highly negatively charged bacterial wall molecules was proposed to involve the lysine residues at the surface of TCTP (92). BmTCTP also tends to bind bacteria such as Bacillus bombyseptieus or Serratia marcescens. In response to PAMP, BmTCTP induces the production of anti-microbial peptides through the ERK pathway (92). Therefore, BmTCTP contributes to the insect intestinal immunity by acting as opsonin to enhance phagocytosis. To the best of our knowledge, no mammalian TCTP has been reported to date to bind saccharides (other than nucleic acids). Considering that peptide cell-penetration often involves recognition of cell-surface carbohydrates, this study on BmTCTP could inspire future research for a better characterization of the mechanism of TCTP cell penetration.

\section{Structural aspects of TCTP in complex with proteins}

\section{TCTP directly interacts with dozens of proteins}

Over the years, the number of proteins that interact in vivo with TCTP has progressively increased and several dozens of TCTP partners have been identified and further confirmed in vitro, by pull-down assays for example. One review by Amson et al. (2) reported the extensive list of partners known in 2013. These partners were classified according to their functions as antiapoptotic, GTPases, p53 axis, cytoskeleton/mitotic machinery, DNA processing and repair and RNA/ribosome/protein biogenesis. This protein repertoire has continuously expanded to include for example proteins such as 14-3-3 (93), Apaf-1 (94), HSPA9 (95), YBX1 (95), HSP27 (96), peroxiredoxin-1 (97), ATG16 complex (98), nucleolin (99), or IgE/IgG (100). 
Despite the ever-accumulating evidence of the functional importance of TCTP and of its interaction with partners, the amount of structural information regarding protein-protein interaction (PPI) is yet rather limited. Each discovery of novel TCTP-related PPI is often associated to attempts to decipher the molecular basis of the PPI through peptide fragments approaches. In such strategies, peptides derived from the native proteins are designed and the analysis of the preservation of peptide-peptide contacts leads to the identification of the protein region(s) important for the interaction under scrutiny. The TCTP-related PPI analyzed using peptide fragments were summed up in a review in 2012 (1). Because several novel interactions have been identified and characterized meanwhile, we propose an updated table of interactions in Table 2. Partners identified by coimmunoprecipitation or two-hybrid techniques may be indirect by the implication of a third partner. It is therefore crucial to confirm the direct interaction in vitro between recombinant proteins. In this table, two types of interaction were selected amongst the long list of known TCTP partners. On the one hand, we listed interactions confirmed in vitro, whether the biological impact is known or not. On the other hand, we chose interactions with clear biological impacts although the involvement of a third partner is not ruled out yet. The second type was included to foster future in vitro study to confirm biologically relevant interactions.

Table 2 clearly illustrates the versatility of TCTP to bind proteins of distinct cellular functions but also biochemical functions (enzymes, DNA/RNA/protein binding proteins, scaffold proteins,...). The consequences of TCTP binding range from direct enzyme activation or inhibition, protein stabilization by promoting or preventing ubiquitination, protein stabilization in response to heat shock, facilitating or hindering the recruitment of other partners, and the control of phosphorylation of the partner. To play all these functions, TCTP evolved to interact with a large interactome and despite its relatively small size, it proposes different binding modes. Table 2 suggests that almost all TCTP regions are potentially involved in the direct interaction with partners. For example, when mutated, residues Y4, E12, I20, R21, E22, D25, E138 or E168, abrogate binding to a range of partners. All these residues cover a wide surface on TCTP, reinforcing the idea that TCTP does not expose a unique interface for interaction. This parallels the many binding modes observed for the proteins from the $\beta$-tent family (see Figure 3).

\section{Structural informations on native complexes}

The strategy consisting in deleting large portions of protein is extremely efficient when it comes to isolate interacting domains from multidomain proteins. This approach is also useful to identify short peptide fragments from independent folding units such as protein globular domains, in particular when these fragments folds as helices at the interface of protein-protein complex. Nevertheless, short fragments might not properly fold or keep the same 3D conformation as in the native protein. In such situation, the peptide fragment approach is prone to give false negative results. Oppositely, the disruption of the $3 \mathrm{D}$ native fold in short fragments is prone to facilitate non-native interaction, leading to potential false positive results. These limitations may explain some discrepancies observed in the dissection of TCTP interactions as reported in Table 2, such as with the p53 or MDM2 partners. For these reasons, proper interaction analysis are better carried out with native proteins, preferentially with full length proteins or at least by preserving folding units, followed by point mutations. To date, our understanding of TCTP interactions using native proteins is limited to the TCTP/eEF1B $\delta$ complex, for which a high-resolution structure have been obtained from a mixed approach based on classical NMR-based structure determination followed by molecular docking driven by experimental NMR data (36) (see Figure 5A). This 
structure was validated by extensive site-directed mutagenesis and highlighted the role of the helical hairpin (Site I) and of a surface patch (Site II) formed by the stretch connecting helices $\alpha 1$ and $\alpha 2$ and including strand $\beta 7$ (around F83) and the loop $\beta 8-\beta 9$ (containing M140 and $\mathrm{P} 142$ ) in the interaction with the CAR domain from eEF1B (Figure 5A). In the complex the negatively charged N-terminus of CAR adopts an extended conformation that wraps around the positively charged helical hairpin, including residues K90, I92, K93, M96, K97, K100, M115, T116, A118, A119, and I122. At its C-terminus, CAR adopts an $\alpha$-helical conformation that docks on a surface overlapping sites I and II through hydrophobic contacts with F83, M140, P142 and electrostatic contacts with D143 and D94. Electrostatic and hydrophobic interactions both contribute to stabilize the complex.

This work provides the most convincing study of the key role of the helical hairpin in TCTP PPI. It is most likely that this structure element is also involved in other PPIs as suggested from other studies $(53,100-104)$, with strong functional impacts such as in apoptosis (8). Another hint about the key role of the helical hairpin is provided by a structural model of the complex formed by TCTP and the N-terminal domain of MDM2 (Figure 5B). The molecular interface of this complex has been well characterized on MDM2 side by competition with well-known MDM2 binder (nutlin-3) or by using MDM2 mutants (M62A). However, the interface on TCTP still awaits validation with high resolution structural data from native protein and/or from point mutations. This could also resolve the somehow inconsistent results obtained from independent studies on TCTP/MDM2 interaction $(53,104)$.

The TCTP/Bcl-xL complex is the only TCTP complex for which a crystal structure has been obtained (Figure 5C). The TCTP/Bcl-xL complex with full-length proteins could be purified but only a complex of Bcl-xL with a peptide derived from the TCTP BH3-like domain was crystallized. This structure illustrates how the TCTP BH3-like peptide binds to the BH3 binding groove of Bcl-xL (45). The crystal contained a swapped dimeric Bcl-xL, which appears to be an hallmark of this protein. Six TCTP peptides were observed, although only two of them were considered as significant. This work (45) provided sound basis to demonstrate the existence of a functional BH3-like element in TCTP, but at the same time, raises novel questions. The BH3-like domain (residues 16 to 27) folds as strand $\beta 3$ in the native TCTP structure and undergoes a severe conformational rearrangement in the complex with Bcl-xL. Because residues 16 to 27 play a key role in stabilizing TCTP larger $\beta$-sheet, it is difficult to predict the impact of the global conformation change of TCTP in the complex: is strand $\beta 3$ the only element being affected? does TCTP completely unfold and remain unfolded at the exception of the helical BH3 region? does TCTP remold into another stable conformation unrelated to the fold of the unbound protein? does other region than the $\mathrm{BH} 3$ region of TCTP interact with Bcl-xL? Because TCTP binds at the Bax binding groove of Bcl$\mathrm{xL}$, one would expect that TCTP competes with Bax to inhibit the Bax-mediated antiapoptotic activity of Bcl-xL. Paradoxically, TCTP appears to potentiate the anti-apoptotic activity of Bcl-xL (45). The apparently counter-intuitive structural mechanism by which TCTP activates Bcl-xL remains largely unknown. Clearly, additional structural, thermodynamic and kinetic studies on full-length proteins are required to assess the plasticity of TCTP and to understand its role to control apoptosis. 
A)

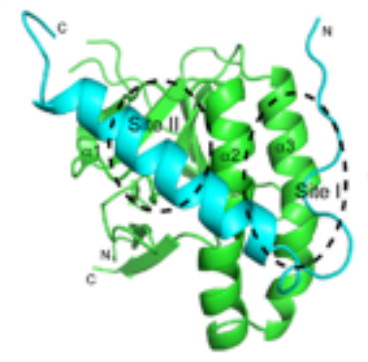

C)

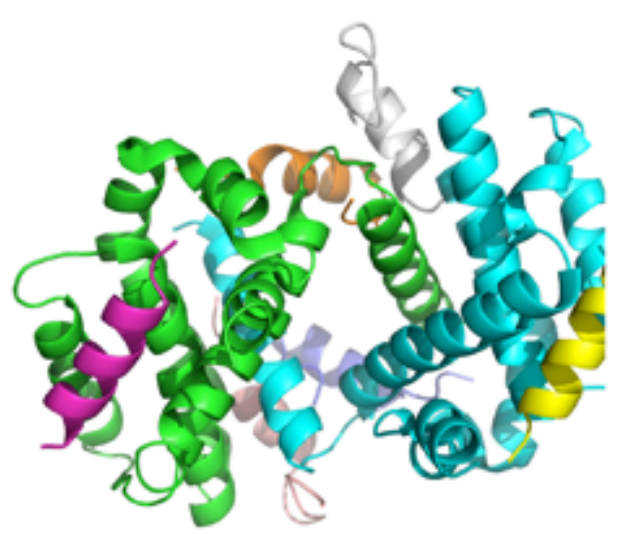

B)
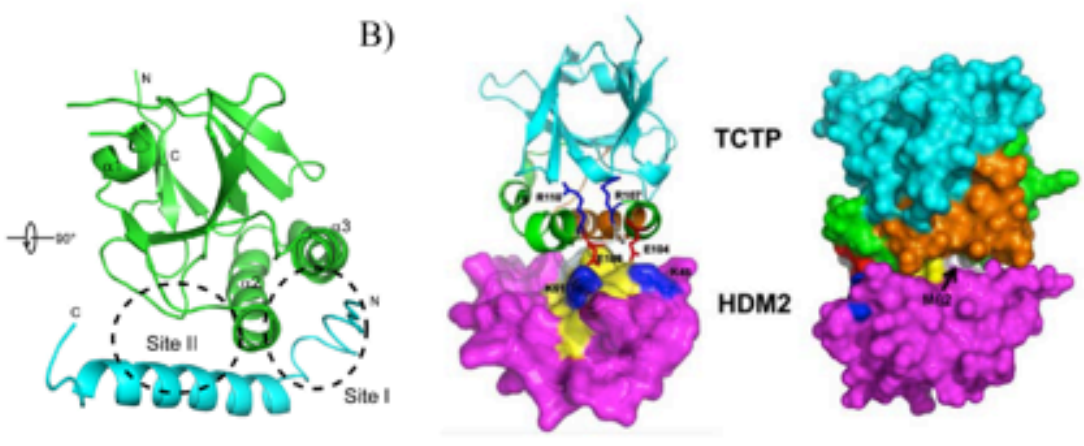

D)

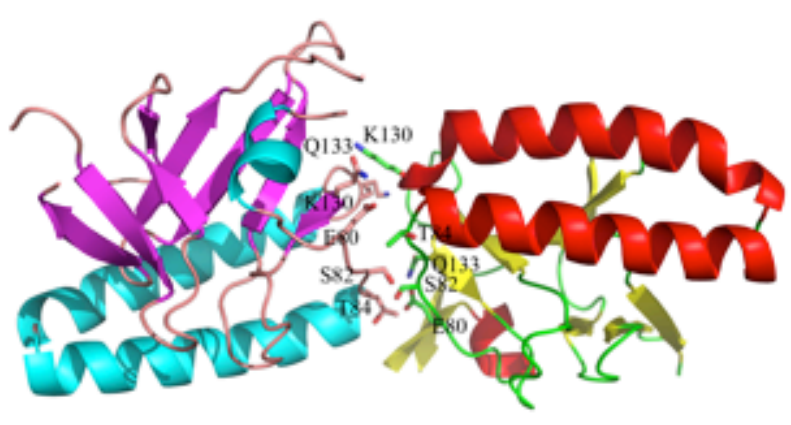

Figure 5: High-resolution structures or structural models of TCTP in interaction with protein partners. (A) NMR-based structure of TCTP in interaction with the CAR domain of eEF1B $\delta$ (36). The two proteins are shown as ribbons with TCTP and eEF1B $\delta$ in green and cyan, respectively. Two orthogonal views are shown. Picture taken with permission from (36). (B) Energy-minimized structural model of the complex between TCTP and the N-terminal domain of human MDM2 obtained from molecular docking based on peptide deletion analysis and MDM2 M62A mutant (104). Picture taken with permission from (104). (C) Structure of the full-length Bcl-xL in complex with the BH3-like domain of TCTP (residues 16-27) (PDB code 4Z9V (45)). The proteins are shown as ribbons. Bcl-xL (cyan and green) crystallized as a swap dimer and six BH3-like peptides were observed (magenta, yellow, orange, grey, salmon, marine). Only the magenta and yellow peptides were considered meaningful, while the other were considered as crystallization artefacts (45). (D) Potential TCTP dimer structure. The chains A and D from the 1YZ1 crystal structure of TCTP are represented as ribbons. The two monomers have different color codes for their secondary structures. The amino-acid residues at the dimer interface are labeled.

\section{TCTP tends to self-associate}

TCTP tends to self-associate. For example, non-covalent dimers/oligomers of rat TCTP have been detected from yeast two-hybrid system (105). The deletion of the region 126-172 resulted in loss of self-interaction of TCTP in vivo (105). The authors concluded that this region was involved in oligomer formation. The amino acids 126-172 encompass the last four $\beta$-strands of TCTP that largely contribute to create the large $\beta$-sheet at the core of TCTP structure. Hence, its deletion is prone to severely impact the proper folding of TCTP and its oligomerization properties. It is therefore highly possible that the peptide missing residues 126-172 is not able to oligomerize because of the global unfolding of the protein, which question the involvement of these residues in oligomerization of the native TCTP. As noted before, heme tends to favor TCTP dimer in vitro with potential role in cellular homeostasis (68). The details of the dimer interface have not been investigated yet. In the analysis of 
TCTP structures so far available, we have noticed that human wild-type and E12V mutant TCTP crystallize with four molecules in the unit cell although they were obtained in different space groups. Interestingly, in the two crystals, an intermolecular interface and a relative protein orientation were clearly conserved between two pairs of molecules. This is illustrated by the contacts between chains $\mathrm{A}$ and $\mathrm{D}$ from the human wild-type structure (Figure 5D). Because this self-association mode is observed in different crystal packings, it is possible that the interactions at this interface of these two molecules are strong enough to exist in solution. We propose that the complex observed between chains A and D could represent the structure of TCTP dimer in solution. The proposed interface is formed by the hydrophilic and charged residues such as E80, S82, T84, Q130 and K133 as highlighted in Figure 5D.

\section{E. Conclusions}

In this chapter we have presented the structural features of TCTP with a focus on its post-translational modifications and interaction network. Despite its relative small size and globular nature, the TCTP structure is extremely versatile and is able to interact with ions, small molecules, carbohydrates, nucleic acids and proteins. Although high-resolution structures and more precise delineation of complex interfaces are still required, it seems that most TCTP surface patches are potential binding hotspots, which might be the hallmark of proteins from the $\beta$-tent family.

To date, our knowledge of the structural property of TCTP in interaction is still very limited. Although the structure of TCTP is apparently highly stable, there are some lines of evidence that TCTP is prone to major rearrangement upon interaction. On the one hand, TCTP interacts with Bcl-xL by the BH3-like domain that is partially buried in the unbound TCTP, suggesting that TCTP undergoes a severe conformational change in the complex. This could explain the difficulty to form the TCTP/Bcl-xL complex (45). To this regard, TCTP also interacts with the Bcl-xL-related Mcl-1, although it is not clear yet if the interaction is also mediated by the BH3-like domain. The formation of TCTP/Mcl-1 complex is also rather difficult and is greatly facilitated by the truncation of the first ten residues (106). It is likely that the removal of the N-terminal residues prevents the proper folding of TCTP. Thus, by alleviating the kinetically-unfavorable unfolding barrier, this truncated TCTP form probably already exposes interacting residues, possibly in the BH3-like region, thus making the formation of the complex easier. Such a truncated form was also proved to be more active to trigger the IgE response (58). Shortened TCTP has not yet been observed in vivo but a TCTP isoform lacking the first 34 amino acids is reported by UniProt (P13693-2), which could have variable binding properties compared to the canonical TCTP isoform. On the other hand, TCTP penetrates cells by using a protein transduction domain that folds as a $\beta$-strand. It is possible that TCTP also undergoes a significant fold rearrangement during cell entry to facilitate recognition and internalization. Future researches are necessary to confirm these hypotheses. Importantly, it will be crucial to identify the molecular triggers, to assess the extent of the conformational change and to assess the functional consequences of the rearrangement on the partners. We speculate that TCTP plasticity greatly contributes to the versatility of its effects on partners and to its multifunctional nature.

One intriguing feature of TCTP is the 30-33 amino acid long flexible loop. This region is very well conserved throughout the phylum, both in length and amino acid composition and contains the TCTP1 signature at its center. Compared to structured regions, flexible regions are in general less under evolution constraints of keeping structurally important amino acids and are therefore prone to vary in length and composition. The conservation of the loop in TCTP therefore suggests that other forces drive its conservation during evolution. In particular one may wonder if the loop directly interacts with partners, if it controls the access 
to other binding hotspots on TCTP, of if it contributes to the proposed conformational rearrangement. For this, it is crucial to characterize complexes between native proteins, with a focus on the dynamics of this loop. The loop might be involved in other regulatory events such as the phosphorylation of serines S46, S53 or S64. Being part of TCTP1 signature, S53 is strictly conserved and its phosphorylation could regulate biological functions shared throughout the phylum. In contrast, S46 and S64 are found only in mammalian TCTP, and most likely regulate mammalian-specific functions. The impact of phosphorylation on the dynamics of the loop, and beyond, on the structure of the protein will also provide insights into the role of the loop.

Although our knowledge of TCTP functions has greatly expanded over the last years, much remains to be done to characterize the biochemical and structural features of TCTP. No doubt that such gain in knowledge will contribute to decipher the multiple functions of TCTP in physiological and pathophysiological processes. 
Table 1: The list of non proteic molecules interacting with TCTP is shown in this table. The species in which the interactions have been observed as well that some functional insights into the interaction are also reported.

\begin{tabular}{|c|c|c|c|}
\hline Binding Partner & Species & Function and distribution & Ref. \\
\hline calcium $\left(\mathrm{Ca}^{2+}\right)$ & $\begin{array}{l}\text { Trypanosoma brucei, Schistosoma } \\
\text { mansoni, rat, human }\end{array}$ & Regulation of $\mathrm{Ca}^{2+}$ homeostasis and $\mathrm{Ca}^{2+}$-induced apoptosis. & $\begin{array}{l}(7,59 \\
61-69)\end{array}$ \\
\hline $\begin{array}{l}\text { Sertraline / thioridazine / } \\
\text { levomepromazine } \\
\text { buclizine }\end{array}$ & human & Anti-histaminic and anti-histaminic-related small molecules. & $\begin{array}{ll}(53,70 \\
72)\end{array}$ \\
\hline \multirow[t]{2}{*}{ peptides } & human & WGQWPYHC with specific cytotoxicity against tumor cells. & $(74)$ \\
\hline & human & $\begin{array}{l}\text { WYVYPSM and WEFPGWM against the covalent dimeric } \\
\text { TCTP. }\end{array}$ & $(73)$ \\
\hline $\begin{array}{l}\text { artemisinin } \quad \text { and } \\
\text { analogues }\end{array}$ & Plasmodium falciparum, human & $\begin{array}{l}\text { TCTP is targeted and covalently modified by artemisinin and } \\
\text { analogues, possibly at multiple sites from F12 to Y } 22 \text { in } \\
\text { PfTCTP. }\end{array}$ & $\begin{array}{ll}(3, & 75 \\
80) & \end{array}$ \\
\hline heme & human & Heme binds TCTP and promotes its dimerization. & $(68)$ \\
\hline $\begin{array}{l}\text { DNA (Sf1 promoter of } \\
\text { oct } 4)^{*}\end{array}$ & $\begin{array}{l}\text { Xenopus oocyte, } \\
\text { human }\end{array}$ & Activates transcription of oct 4 and nanog. & $\begin{array}{l}(88) \text { See } \\
\text { also }(89)\end{array}$ \\
\hline mRNA* & HeLa Cells & TCTP belongs to mRNA interactome & $(91)$ \\
\hline $\begin{array}{l}\text { chitin, } \\
\text { lipopolysaccharide, } \\
\text { peptidoglycans, } \mathrm{Bb} \\
\text { (Bacillus } \\
\text { bombyseptieus), } \mathrm{Sm} \\
\text { (Serratia marcescens) }\end{array}$ & Bombyx mori & $\begin{array}{l}\text { TCTP as a novel opsonic molecule. Induces the production of } \\
\text { anti-microbial peptide. }\end{array}$ & $(92)$ \\
\hline
\end{tabular}

*: the interactions of TCTP with DNA and RNA was observed in oocyte extracts and in HeLa cells respectively, and have not been confirmed yet in vitro. 
Table 2: The list of proteic partners identified for TCTP is shown in this table. We have reported here partners for which the interaction has been confirmed in vitro using recombinant proteins. Other interactions waiting for in vitro confirmation have also been included (proteins indicated by a star) when functional information of particular interest has been reported. When available, the amino acids and domains of TCTP and partners involved in the interaction are indicated. $n d$ means "not determined". When point mutants were shown to disrupt the intermolecular interaction, the single amino acid is reported. In the case of $\mathrm{eEF} 1 \mathrm{~B} \delta$, we listed the amino acids that are present at interface of the complex.

\begin{tabular}{|c|c|c|c|c|c|c|}
\hline & Binding Partner & Species & TCTP & Partner & Function and distribution & Ref. \\
\hline \multirow[t]{10}{*}{\begin{tabular}{|l|} 
Cell \\
cycle \\
mitosis
\end{tabular}} & $\alpha$-tubulin & mouse & $70-130$ & nd & \multirow{3}{*}{$\begin{array}{l}\text { Stabilizes microtubule. Colocalizes } \\
\text { with microtubules in the } \mathrm{G} 1, \mathrm{~S}, \mathrm{G} 2 \\
\text { and early } \mathrm{M} \text { phases of cell cycle. } \\
\text { Regulates spindle microtubule } \\
\text { dynamics and cell shape. }\end{array}$} & $(102)$ \\
\hline & $\beta$-tubulin & mouse & $70-130$ & nd & & (102) \\
\hline & $\begin{array}{ll}\text { Centrosome } & \text { and } \\
\text { Microtubules* } & \end{array}$ & $\begin{array}{l}\text { Xenopus } \\
\text { laevis, } \\
\text { mammalian } \\
\text { cells } \\
\end{array}$ & nd & nd & & $\begin{array}{l}(46,107,108) \\
\text { See also }(95)\end{array}$ \\
\hline & Actin & rabbit & $75-97$ & nd & $\begin{array}{l}\text { TCTP binds preferentially to G- } \\
\text { actin than to F-actin. }\end{array}$ & $\begin{array}{lll}(47) . & \text { See } & \text { also } \\
(95) & & \end{array}$ \\
\hline & $\begin{array}{l}\text { CHFR (Checkpoint } \\
\text { protein with FHA and RING } \\
\text { finger domain )* }\end{array}$ & human & nd & nd & $\begin{array}{l}\text { CHFR interacts and colocalizes } \\
\text { with TCTP to the mitotic spindle. }\end{array}$ & (109) \\
\hline & Plk1 (polo-like kinase 1) & $\begin{array}{l}\text { mouse / } \\
\text { human }\end{array}$ & $107-172$ & Polo box & $\begin{array}{l}\text { Plk1 phosphorylates TCTP on S46 } \\
\text { and S64, which is required for } \\
\text { proper mitosis. }\end{array}$ & $\begin{array}{lll}\left(\begin{array}{l}(49) . \\
(52)\end{array}\right. & \text { See } & \text { also } \\
\end{array}$ \\
\hline & Nucleophosmine* (Mpm1) & mouse & nd & nd & $\begin{array}{l}\text { The Mpm1/TCTP complex is a } \\
\text { potential biomarker for mitotic ES } \\
\text { cells. }\end{array}$ & $(110)$ \\
\hline & Nucleolin* & mouse & nd & nd & $\begin{array}{l}\text { Interaction with phosphorylated } \\
\text { nucleolin observed during mitosis. }\end{array}$ & (99) \\
\hline & $\begin{array}{l}\text { Rheb (Ras homolog enriched } \\
\text { in brain) }\end{array}$ & $\begin{array}{l}\text { human } \\
\text { drosophila }\end{array}$ & $\begin{array}{l}\text { E12, K90, } \\
\text { E138 }\end{array}$ & Y35, K45 & $\begin{array}{l}\text { Preferential binds to nucleotide-free } \\
\text { Rheb. Stimulates the GTP/GDP } \\
\text { exchange on Rheb to control } \\
\text { mTORC1-dependent cell growth } \\
\text { and proliferation. }\end{array}$ & $\begin{array}{l}(9,19) \text {. See also } \\
(111) \text { Two other } \\
\text { studies }(20,21) \\
\text { seriously } \\
\text { questioned this } \\
\text { interaction and } \\
\text { function. }\end{array}$ \\
\hline & $\begin{array}{l}14-3-3(14-3-3 \varepsilon \text { or } 14-3-3 \zeta \\
\text { isoforms) }\end{array}$ & drosophila & nd & nd & $\begin{array}{l}\text { Required for TCTP-Rheb } \\
\text { interaction. }\end{array}$ & $(93)$ \\
\hline \multirow[t]{11}{*}{$\begin{array}{l}\text { Survival / } \\
\text { apoptosis }\end{array}$} & \multirow[t]{3}{*}{$\mathrm{p} 53$} & human & $70-119$ & \begin{tabular}{|l|}
$101-300$ \\
binding domain)
\end{tabular} & \multirow{3}{*}{$\begin{array}{l}\text { Destabilizes p53 and blocks p53- } \\
\text { induced transcriptional activation of } \\
\text { Bax. }\end{array}$} & (103) \\
\hline & & human & $\begin{array}{l}1-70+121- \\
172+\mathrm{Y} 4+ \\
\mathrm{E} 168\end{array}$ & \begin{tabular}{|l|}
$103-292$ (DNA \\
binding domain)
\end{tabular} & & $(112)$ \\
\hline & & human & nd & \begin{tabular}{|l|}
$99-293+294-$ \\
393
\end{tabular} & & $(53)$ \\
\hline & NUMB & human & $1-68$ & $20-259$ & $\begin{array}{l}\text { Competes with NUMB for binding } \\
\text { to MDM2. }\end{array}$ & (53) \\
\hline & \multirow[t]{2}{*}{$\begin{array}{lll}\text { MDM2 (murine } & \text { double } \\
\text { minute 2) } & & \end{array}$} & human & $1-68$ & \begin{tabular}{|l}
$134-333+$ \\
$302-435$ \\
\end{tabular} & \multirow{2}{*}{$\begin{array}{l}\text { TCTP inhibits MDM2 auto- } \\
\text { ubiquitination and promotes } \\
\text { MDM2-mediated ubiquitination. }\end{array}$} & (53) \\
\hline & & & $80-133$ & $44-65+\mathrm{M} 62$ & & $(104)$ \\
\hline & \multirow[t]{2}{*}{$\begin{array}{l}\text { Bcl-xL (B-cell lymphoma- } \\
\text { extra large) }\end{array}$} & mouse & $\begin{array}{l}\text { 1-40, } \\
\text { R21, } \\
\text { D25, }\end{array}$ & 1-188, L90, D95 & \multirow[t]{2}{*}{$\begin{array}{l}\text { Potentiates the anti-apoptotic } \\
\text { activity of Bcl-xL. }\end{array}$} & $(44)$ \\
\hline & & human & $14-29, \mathrm{R} 21$ & $\begin{array}{l}\text { BH3-binding } \\
\text { domain }\end{array}$ & & $(45)$ \\
\hline & \multirow{2}{*}{$\begin{array}{lr}\text { Mcl-1 (Induced Myeloid } \\
\text { Leukemia } & \text { Cell } \\
\text { Differentiation Protein) } & \end{array}$} & human & $5-172, \mathrm{R} 21$ & nd & \multirow[t]{2}{*}{$\begin{array}{l}\text { Mcl-1 stabilizes TCTP and TCTP } \\
\text { inhibits ubiquitination of Mcl-1. }\end{array}$} & $(113)$ \\
\hline & & $\begin{array}{l}\text { mouse/ } \\
\text { human }\end{array}$ & $14-94$ & K257 & & $(106)$ \\
\hline & $\begin{array}{l}\text { Apaf-1 (Apoptotic peptidase } \\
\text { activating factor 1) }\end{array}$ & human & nd & \begin{tabular}{|l|l|} 
1-97 (CARD \\
domain)
\end{tabular} & $\begin{array}{l}\text { Inhibits the etoposide-induced } \\
\text { cell death. }\end{array}$ & (94) \\
\hline
\end{tabular}




\begin{tabular}{|c|c|c|c|c|c|c|}
\hline & $\begin{array}{l}\text { TSC-22 (Transforming } \\
\text { growth factor-beta } \\
\text { stimulated clone-22) }\end{array}$ & human & $1-69$ & $53-110$ & $\begin{array}{l}\text { Prevents TSC-22 mediated } \\
\text { apoptosis via the destabilization of } \\
\text { TSC- } 22 \text {. }\end{array}$ & $(114)$ \\
\hline \multirow[t]{4}{*}{$\begin{array}{l}\text { Protein } \\
\text { synthesis }\end{array}$} & $\begin{array}{l}\text { eEF1A (eukaryotic } \\
\text { translation elongation factor } \\
1 \text { alpha) }\end{array}$ & human & nd & nd & \multirow{3}{*}{$\begin{array}{l}\text { Preferentially binds GDP form of } \\
\text { eEF1A and specifically } \\
\text { antagonizes the eEF1B } \delta \text {-mediated } \\
\text { guanine nucleotide exchange } \\
\text { reaction. Partially colocalize around } \\
\text { the nucleus. }\end{array}$} & $\begin{array}{lll}(18) . & \text { See } & \text { also } \\
(115) & & \end{array}$ \\
\hline & \multirow[t]{2}{*}{ eEF1B $\delta$} & human & nd & $153-281$ & & $\begin{array}{lll}(18) . & \text { See } & \text { also } \\
(116) & & \end{array}$ \\
\hline & & human & $\begin{array}{lr}\text { F83, } & \text { K90, } \\
\text { I92, } & \text { K93, } \\
\text { D94, } & \text { M96, } \\
\text { K97, } & \text { K100, } \\
\text { M115, } & \text { T116, } \\
\text { A118, } & \text { A119, } \\
\text { I122, } & \text { M140, } \\
\text { P142, } & \text { D143 }\end{array}$ & $\begin{array}{ll}\text { 155-189 (CAR } \\
\text { domain) }\end{array}$ & & $\begin{array}{l}(36) \text { high } \\
\text { resolution } \\
\text { structural model }\end{array}$ \\
\hline & 40S ribosomal subunit & Yeast & nd & nd & $\begin{array}{l}\text { Copurified with ribosomal complex. } \\
\text { Required for efficient translation. }\end{array}$ & (117) \\
\hline \multirow[t]{2}{*}{$\begin{array}{l}\text { DNA } \\
\text { damage } \\
\text { repair }\end{array}$} & $\begin{array}{l}\text { ATM (ataxia telangiectasia } \\
\text { mutated) }\end{array}$ & drosophila & \begin{tabular}{ll|}
$61-120$ & + \\
$121-172$ & + \\
E12 &
\end{tabular} & $1006-1215$ & $\begin{array}{l}\text { Enhances the binding } \\
\text { affinity of dATM to its substrate to } \\
\text { promote efficient DNA repair. }\end{array}$ & $\begin{array}{l}\text { (118) and related } \\
\text { (34) }\end{array}$ \\
\hline & 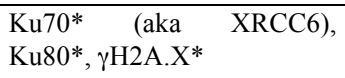 & human & nd & nd & $\begin{array}{l}\text { DNA double-strand break sensing } \\
\text { and repair. }\end{array}$ & $(34,95)$ \\
\hline \multirow[t]{16}{*}{ Others } & $\begin{array}{l}\text { TSAP6 (tumor suppressor- } \\
\text { activated pathway 6) }\end{array}$ & human & nd & nd & $\begin{array}{l}\text { TSAP6 augments TCTP secretion } \\
\text { through exosome. }\end{array}$ & (43) \\
\hline & $\mathrm{Na}, \mathrm{K}-\mathrm{ATPase}$ & rat / human & $102-172$ & $\begin{array}{l}\text { Cytoplasmic } \\
\text { domain CD3 }\end{array}$ & Suppresses Na, K-ATPase activity. & (119) \\
\hline & Sorting nexin 6 (SNX6)* & rat/ human & nd & nd & $\begin{array}{l}\text { Suppresses the TCTP mediated } \\
\text { inhibition of } \mathrm{Na}, \mathrm{K} \text {-ATPase. }\end{array}$ & $(120)$ \\
\hline & TCTP (self-association) & rat & $126-172$ & na & nd & $\begin{array}{l}(105) . \text { See also } \\
(68)\end{array}$ \\
\hline & Vitamin D3 receptor & human & $71-132$ & $197-427$ & $\begin{array}{l}\text { Oxidative stress leads to } \\
\text { colocalization in the nucleus. }\end{array}$ & $(101)$ \\
\hline & $\begin{array}{l}\text { Fortilin-binding protein } 1 \\
\text { (FBP1) }\end{array}$ & shrimp & $37-63$ & $44-51+77-88$ & $\begin{array}{l}\text { Protection against the widespread } \\
\text { White Spot Syndrome Virus } \\
\text { infection. }\end{array}$ & $(121,122)$ \\
\hline & $\begin{array}{l}\text { Tumour suppressor } \quad \text { VHL } \\
\text { (von Hippel-Lindau) }\end{array}$ & human & nd & $\beta$ domain & $\begin{array}{l}\text { TCTP binds to the } \beta \text { domain of } \\
\text { VHL through competition with } \\
\text { HIF1 } \alpha \text {, which promotes VHL } \\
\text { degradation by the ubiquitin- } \\
\text { proteasome system and HIF1 } \alpha \\
\text { stability. }\end{array}$ & (123) \\
\hline & $\begin{array}{l}\text { IgE, IgG (Immunoglobulin E } \\
\text { and } G \text { ) }\end{array}$ & $\begin{array}{l}\text { mouse } \\
\text { human }\end{array}$ & $\begin{array}{ll}1-19, & 107- \\
135 & \end{array}$ & $\mathrm{Fab}$ & $\begin{array}{l}\text { Stimulate IgE-bound mast cells. } \\
K_{D}=\sim 1 \mu \mathrm{M}\end{array}$ & $\begin{array}{l}\text { (100). See also } \\
(124)\end{array}$ \\
\hline & Peroxiredoxin-1 (PRDX1) & human & nd & nd & $\begin{array}{l}\text { Potentiates the peroxidase activity } \\
\text { of Peroxiredoxin- } 1 \text { by regulating its } \\
\text { phosphorylation. } K_{D} \text { of } 125 \mathrm{nM} \text {. }\end{array}$ & $\begin{array}{lll}(97) . & \text { See } & \text { also } \\
(95) & & \end{array}$ \\
\hline & $\begin{array}{l}\text { SWI/SNF (SWItch/Sucrose } \\
\text { Non-Fermentable) and its } \\
\text { homologue in drosophila } \\
\text { Brahma }\end{array}$ & drosophila & E12 & $\begin{array}{lr}304-747 & \text { (HSA } \\
\text { and } & \text { BRK } \\
\text { domains) } & \\
\end{array}$ & $\begin{array}{l}\text { Negatively modulates } \text { Brahma } \\
\text { activity in transcription. }\end{array}$ & $(35,125)$ \\
\hline & $\begin{array}{ll}\text { YBX1 } & \text { (Y-box-binding } \\
\text { protein 1) } & \\
\end{array}$ & Human & $42-83$ & $1-129$ & nd & $(95)$ \\
\hline & $\begin{array}{l}\text { Marek's disease virus } \\
\text { (MDV)-specific protein R- } \\
\text { LORF12 }\end{array}$ & chicken & nd & nd & nd & $(126)$ \\
\hline & $\begin{array}{l}\text { Oct4 (octamer-binding } \\
\text { transcription factor } 4)\end{array}$ & mouse & nd & nd & $\begin{array}{l}\text { Controls genes involved in } \\
\text { embryonic development. }\end{array}$ & $(90)$ \\
\hline & $\begin{array}{l}\text { ATG16 (Autophagy protein } \\
16)^{*}\end{array}$ & nd & nd & nd & Regulation of autophagy & (98) \\
\hline & $\begin{array}{l}\text { TCF-4 (Transcription factor } \\
4)^{*}\end{array}$ & human & nd & nd & $\begin{array}{l}\text { Enhances } \quad \beta \text {-catenin/TCF-4 } \\
\text { transcription activity. }\end{array}$ & (127) \\
\hline & $\begin{array}{l}\text { HSP27 (Heat-Shock Protein } \\
27)^{*}\end{array}$ & human & nd & nd & $\begin{array}{l}\text { Protects TCTP from the } \\
\text { ubiquitin-proteasome degradation. }\end{array}$ & $\begin{array}{l}(128) \text { and the } \\
\text { related }(71)\end{array}$ \\
\hline
\end{tabular}




\section{References}

1. Kawakami T, Ando T, \& Kawakami Y (2012) HRF-interacting molecules. The Open Allergy Journal 5(41-46).

2. Amson R, Pece S, Marine JC, Di Fiore PP, \& Telerman A (2013) TPT1/ TCTPregulated pathways in phenotypic reprogramming. Trends in cell biology 23(1):37-46.

3. Eichhorn T, Winter D, Buchele B, Dirdjaja N, Frank M, Lehmann WD, Mertens R, Krauth-Siegel RL, Simmet T, Granzin J, \& Efferth T (2013) Molecular interaction of artemisinin with translationally controlled tumor protein (TCTP) of Plasmodium falciparum. Biochemical pharmacology 85(1):38-45.

4. Vedadi M, Lew J, Artz J, Amani M, Zhao Y, Dong A, Wasney GA, Gao M, Hills T, Brokx S, Qiu W, Sharma S, Diassiti A, Alam Z, Melone M, Mulichak A, Wernimont A, Bray J, Loppnau P, Plotnikova O, Newberry K, Sundararajan E, Houston S, Walker J, Tempel W, Bochkarev A, Kozieradzki I, Edwards A, Arrowsmith C, Roos D, Kain K, \& Hui R (2007) Genome-scale protein expression and structural biology of Plasmodium falciparum and related Apicomplexan organisms. Molecular and biochemical parasitology 151(1):100-110.

5. Thaw P, Baxter NJ, Hounslow AM, Price C, Waltho JP, \& Craven CJ (2001) Structure of TCTP reveals unexpected relationship with guanine nucleotide-free chaperones. Nature structural biology 8(8):701-704.

6. Lange OF, Rossi P, Sgourakis NG, Song Y, Lee HW, Aramini JM, Ertekin A, Xiao R, Acton TB, Montelione GT, \& Baker D (2012) Determination of solution structures of proteins up to $40 \mathrm{kDa}$ using CS-Rosetta with sparse NMR data from deuterated samples. Proceedings of the National Academy of Sciences of the United States of America 109(27):10873-10878.

7. Feng Y, Liu D, Yao H, \& Wang J (2007) Solution structure and mapping of a very weak calcium-binding site of human translationally controlled tumor protein by NMR. Archives of biochemistry and biophysics 467(1):48-57.

8. Susini L, Besse S, Duflaut D, Lespagnol A, Beekman C, Fiucci G, Atkinson AR, Busso D, Poussin P, Marine JC, Martinou JC, Cavarelli J, Moras D, Amson R, \& Telerman A (2008) TCTP protects from apoptotic cell death by antagonizing bax function. Cell death and differentiation 15(8):1211-1220.

9. Dong X, Yang B, Li Y, Zhong C, \& Ding J (2009) Molecular basis of the acceleration of the GDP-GTP exchange of human ras homolog enriched in brain by human translationally controlled tumor protein. The Journal of biological chemistry 284(35):23754-23764.

10. Lupas AN, Zhu H, \& Korycinski M (2015) The thalidomide-binding domain of cereblon defines the CULT domain family and is a new member of the beta-tent fold. PLoS Comput Biol 11(1):e1004023.

11. Robert X \& Gouet P (2014) Deciphering key features in protein structures with the new ENDscript server. Nucleic Acids Res 42(Web Server issue):W320-324.

12. Fischer ES, Bohm K, Lydeard JR, Yang H, Stadler MB, Cavadini S, Nagel J, Serluca F, Acker V, Lingaraju GM, Tichkule RB, Schebesta M, Forrester WC, Schirle M, Hassiepen U, Ottl J, Hild M, Beckwith RE, Harper JW, Jenkins JL, \& Thoma NH (2014) Structure of the DDB1-CRBN E3 ubiquitin ligase in complex with thalidomide. Nature 512(7512):49-53. 
13. Lu C, Xu H, Ranjith-Kumar CT, Brooks MT, Hou TY, Hu F, Herr AB, Strong RK, Kao CC, \& Li P (2010) The structural basis of 5' triphosphate double-stranded RNA recognition by RIG-I C-terminal domain. Structure 18(8):1032-1043.

14. Subramanian L, Medina-Pritchard B, Barton R, Spiller F, Kulasegaran-Shylini R, Radaviciute G, Allshire RC, \& Arockia Jeyaprakash A (2016) Centromere localization and function of Mis 18 requires Yippee-like domain-mediated oligomerization. EMBO Rep 17(4):496-507.

15. Itzen A, Pylypenko O, Goody RS, Alexandrov K, \& Rak A (2006) Nucleotide exchange via local protein unfolding--structure of Rab8 in complex with MSS4. EMBO J 25(7):1445-1455.

16. Ranaivoson FM, Neiers F, Kauffmann B, Boschi-Muller S, Branlant G, \& Favier F (2009) Methionine sulfoxide reductase B displays a high level of flexibility. $J$ Mol Biol 394(1):83-93.

17. Lowther WT, Weissbach H, Etienne F, Brot N, \& Matthews BW (2002) The mirrored methionine sulfoxide reductases of Neisseria gonorrhoeae pilB. Nature structural biology 9(5):348-352.

18. Cans C, Passer BJ, Shalak V, Nancy-Portebois V, Crible V, Amzallag N, Allanic D, Tufino R, Argentini M, Moras D, Fiucci G, Goud B, Mirande M, Amson R, \& Telerman A (2003) Translationally controlled tumor protein acts as a guanine nucleotide dissociation inhibitor on the translation elongation factor eEF1A. Proceedings of the National Academy of Sciences of the United States of America 100(24):13892-13897.

19. Hsu YC, Chern JJ, Cai Y, Liu M, \& Choi KW (2007) Drosophila TCTP is essential for growth and proliferation through regulation of dRheb GTPase. Nature 445(7129):785-788.

20. Rehmann H, Bruning M, Berghaus C, Schwarten M, Kohler K, Stocker H, Stoll R, Zwartkruis FJ, \& Wittinghofer A (2008) Biochemical characterisation of TCTP questions its function as a guanine nucleotide exchange factor for Rheb. FEBS letters 582(20):3005-3010.

21. Wang X, Fonseca BD, Tang H, Liu R, Elia A, Clemens MJ, Bommer UA, \& Proud CG (2008) Re-evaluating the roles of proposed modulators of mammalian target of rapamycin complex 1 (mTORC1) signaling. The Journal of biological chemistry 283(45):30482-30492.

22. Iovine B, Iannella ML, \& Bevilacqua MA (2011) Damage-specific DNA binding protein 1 (DDB1): a protein with a wide range of functions. The international journal of biochemistry \& cell biology 43(12):1664-1667.

23. Ito T, Ando H, Suzuki T, Ogura T, Hotta K, Imamura Y, Yamaguchi Y, \& Handa H (2010) Identification of a primary target of thalidomide teratogenicity. Science 327(5971):1345-1350.

24. Kronke J, Fink EC, Hollenbach PW, MacBeth KJ, Hurst SN, Udeshi ND, Chamberlain PP, Mani DR, Man HW, Gandhi AK, Svinkina T, Schneider RK, McConkey M, Jaras M, Griffiths E, Wetzler M, Bullinger L, Cathers BE, Carr SA, Chopra R, \& Ebert BL (2015) Lenalidomide induces ubiquitination and degradation of CK1alpha in del(5q) MDS. Nature 523(7559):183-188.

25. Petzold G, Fischer ES, \& Thoma NH (2016) Structural basis of lenalidomide-induced CK1alpha degradation by the CRL4(CRBN) ubiquitin ligase. Nature 532(7597):127130.

26. Xu Q, Hou YX, Langlais P, Erickson P, Zhu J, Shi CX, Luo M, Zhu Y, Xu Y, Mandarino LJ, Stewart K, \& Chang XB (2016) Expression of the cereblon binding 
protein argonaute 2 plays an important role for multiple myeloma cell growth and survival. BMC cancer 16:297.

27. Stellfox ME, Nardi IK, Knippler CM, \& Foltz DR (2016) Differential Binding Partners of the Mis18alpha/beta YIPPEE Domains Regulate Mis18 Complex Recruitment to Centromeres. Cell Rep 15(10):2127-2135.

28. Leung DW \& Amarasinghe GK (2012) Structural insights into RNA recognition and activation of RIG-I-like receptors. Curr Opin Struct Biol 22(3):297-303.

29. Leung DW \& Amarasinghe GK (2016) When your cap matters: structural insights into self vs non-self recognition of 5' RNA by immunomodulatory host proteins. Curr Opin Struct Biol 36:133-141.

30. Cui S, Eisenacher K, Kirchhofer A, Brzozka K, Lammens A, Lammens K, Fujita T, Conzelmann KK, Krug A, \& Hopfner KP (2008) The C-terminal regulatory domain is the RNA 5'-triphosphate sensor of RIG-I. Mol Cell 29(2):169-179.

31. Hinojosa-Moya J, Xoconostle-Cazares B, Piedra-Ibarra E, Mendez-Tenorio A, Lucas WJ, \& Ruiz-Medrano R (2008) Phylogenetic and structural analysis of translationally controlled tumor proteins. Journal of molecular evolution 66(5):472-483.

32. Dephoure N, Zhou C, Villen J, Beausoleil SA, Bakalarski CE, Elledge SJ, \& Gygi SP (2008) A quantitative atlas of mitotic phosphorylation. Proceedings of the National Academy of Sciences of the United States of America 105(31):10762-10767.

33. Maeng J, Kim M, Lee H, \& Lee K (2015) Insulin induces phosphorylation of serine residues of translationally controlled tumor protein in $293 \mathrm{~T}$ cells. International journal of molecular sciences 16(4):7565-7576.

34. Zhang J, de Toledo SM, Pandey BN, Guo G, Pain D, Li H, \& Azzam EI (2012) Role of the translationally controlled tumor protein in DNA damage sensing and repair. Proceedings of the National Academy of Sciences of the United States of America 109(16):E926-933.

35. Hong ST \& Choi KW (2016) Antagonistic roles of Drosophila Tctp and Brahma in chromatin remodelling and stabilizing repeated sequences. Nature communications 7:12988.

36. Wu H, Gong W, Yao X, Wang J, Perrett S, \& Feng Y (2015) Evolutionarily conserved binding of translationally controlled tumor protein to eukaryotic elongation factor 1B. The Journal of biological chemistry 290(14):8694-8710.

37. Kim M, Kim M, Kim HY, Kim S, Jung J, Maeng J, Chang J, \& Lee K (2011) A protein transduction domain located at the NH2-terminus of human translationally controlled tumor protein for delivery of active molecules to cells. Biomaterials 32(1):222-230.

38. Kim HY, Kim S, Pyun HJ, Maeng J, \& Lee K (2015) Cellular uptake mechanism of TCTP-PTD in human lung carcinoma cells. Molecular pharmaceutics 12(1):194-203.

39. Bae HD \& Lee K (2013) On employing a translationally controlled tumor proteinderived protein transduction domain analog for transmucosal delivery of drugs. Journal of controlled release : official journal of the Controlled Release Society 170(3):358-364.

40. Kim HY, Kim S, Youn H, Chung JK, Shin DH, \& Lee K (2011) The cell penetrating ability of the proapoptotic peptide, KLAKLAKKLAKLAK fused to the N-terminal protein transduction domain of translationally controlled tumor protein, MIIYRDLISH. Biomaterials 32(22):5262-5268.

41. Lee J, Kim S, Shin DH, Kim HJ, \& Lee K (2011) Neuroprotective effect of Cu,Znsuperoxide dismutase fused to a TCTP-derived protein transduction domain. European journal of pharmacology 666(1-3):87-92. 
42. Xiao B, Chen D, Luo S, Hao W, Jing F, Liu T, Wang S, Geng Y, Li L, Xu W, Zhang Y, Liao X, Zuo D, Wu Y, Li M, \& Ma Q (2016) Extracellular translationally controlled tumor protein promotes colorectal cancer invasion and metastasis through Cdc42/JNK/ MMP9 signaling. Oncotarget 7(31):50057-50073.

43. Amzallag N, Passer BJ, Allanic D, Segura E, Thery C, Goud B, Amson R, \& Telerman A (2004) TSAP6 facilitates the secretion of translationally controlled tumor protein/histamine-releasing factor via a nonclassical pathway. The Journal of biological chemistry 279(44):46104-46112.

44. Yang Y, Yang F, Xiong Z, Yan Y, Wang X, Nishino M, Mirkovic D, Nguyen J, Wang $\mathrm{H}$, \& Yang XF (2005) An N-terminal region of translationally controlled tumor protein is required for its antiapoptotic activity. Oncogene 24(30):4778-4788.

45. Thebault S, Agez M, Chi X, Stojko J, Cura V, Telerman SB, Maillet L, Gautier F, Billas-Massobrio I, Birck C, Troffer-Charlier N, Karafin T, Honore J, Senff-Ribeiro A, Montessuit S, Johnson CM, Juin P, Cianferani S, Martinou JC, Andrews DW, Amson R, Telerman A, \& Cavarelli J (2016) TCTP contains a BH3-like domain, which instead of inhibiting, activates Bcl-xL. Scientific reports 6:19725.

46. Bazile F, Pascal A, Arnal I, Le Clainche C, Chesnel F, \& Kubiak JZ (2009) Complex relationship between TCTP, microtubules and actin microfilaments regulates cell shape in normal and cancer cells. Carcinogenesis 30(4):555-565.

47. Tsarova K, Yarmola EG, \& Bubb MR (2010) Identification of a cofilin-like actinbinding site on translationally controlled tumor protein (TCTP). FEBS letters 584(23):4756-4760.

48. Dinkel H, Van Roey K, Michael S, Kumar M, Uyar B, Altenberg B, Milchevskaya V, Schneider M, Kuhn H, Behrendt A, Dahl SL, Damerell V, Diebel S, Kalman S, Klein S, Knudsen AC, Mader C, Merrill S, Staudt A, Thiel V, Welti L, Davey NE, Diella F, \& Gibson TJ (2016) ELM 2016--data update and new functionality of the eukaryotic linear motif resource. Nucleic Acids Res 44(D1):D294-300.

49. Yarm FR (2002) Plk phosphorylation regulates the microtubule-stabilizing protein TCTP. Molecular and cellular biology 22(17):6209-6221.

50. Cucchi U, Gianellini LM, De Ponti A, Sola F, Alzani R, Patton V, Pezzoni A, Troiani S, Saccardo MB, Rizzi S, Giorgini ML, Cappella P, Beria I, \& Valsasina B (2010) Phosphorylation of TCTP as a marker for polo-like kinase-1 activity in vivo. Anticancer research 30(12):4973-4985.

51. Lucibello M, Adanti S, Antelmi E, Dezi D, Ciafre S, Carcangiu ML, Zonfrillo M, Nicotera G, Sica L, De Braud F, \& Pierimarchi P (2015) Phospho-TCTP as a therapeutic target of Dihydroartemisinin for aggressive breast cancer cells. Oncotarget 6(7):5275-5291.

52. Johnson TM, Antrobus R, \& Johnson LN (2008) Plk1 activation by Ste20-like kinase (Slk) phosphorylation and polo-box phosphopeptide binding assayed with the substrate translationally controlled tumor protein (TCTP). Biochemistry 47(12):36883696.

53. Amson R, Pece S, Lespagnol A, Vyas R, Mazzarol G, Tosoni D, Colaluca I, Viale G, Rodrigues-Ferreira S, Wynendaele J, Chaloin O, Hoebeke J, Marine JC, Di Fiore PP, \& Telerman A (2012) Reciprocal repression between P53 and TCTP. Nature medicine 18(1):91-99.

54. Teshima S, Rokutan K, Nikawa T, \& Kishi K (1998) Macrophage colony-stimulating factor stimulates synthesis and secretion of a mouse homolog of a human IgEdependent histamine-releasing factor by macrophages in vitro and in vivo. Journal of immunology (Baltimore, Md. : 1950) 161(11):6356-6366. 
55. Munirathinam G \& Ramaswamy K (2012) Sumoylation of human translationally controlled tumor protein is important for its nuclear transport. Biochemistry research international 2012:831940.

56. Kim W, Bennett EJ, Huttlin EL, Guo A, Li J, Possemato A, Sowa ME, Rad R, Rush J, Comb MJ, Harper JW, \& Gygi SP (2011) Systematic and quantitative assessment of the ubiquitin-modified proteome. Mol Cell 44(2):325-340.

57. Kim M, Maeng J, \& Lee K (2013) Dimerization of TCTP and its clinical implications for allergy. Biochimie 95(4):659-666.

58. Kim M, Min HJ, Won HY, Park H, Lee JC, Park HW, Chung J, Hwang ES, \& Lee K (2009) Dimerization of translationally controlled tumor protein is essential for its cytokine-like activity. PloS one 4(7):e6464.

59. Haghighat NG \& Ruben L (1992) Purification of novel calcium binding proteins from Trypanosoma brucei: properties of 22-, 24- and 38-kilodalton proteins. Molecular and biochemical parasitology 51(1):99-110.

60. Gnanasekar M, Rao KV, Chen L, Narayanan RB, Geetha M, Scott AL, Ramaswamy K, \& Kaliraj P (2002) Molecular characterization of a calcium binding translationally controlled tumor protein homologue from the filarial parasites Brugia malayi and Wuchereria bancrofti. Molecular and biochemical parasitology 121(1):107-118.

61. Rao KV, Chen L, Gnanasekar M, \& Ramaswamy K (2002) Cloning and characterization of a calcium-binding, histamine-releasing protein from Schistosoma mansoni. The Journal of biological chemistry 277(34):31207-31213.

62. Kim M, Jung Y, Lee K, \& Kim C (2000) Identification of the calcium binding sites in translationally controlled tumor protein. Archives of pharmacal research 23(6):633636.

63. Sanchez JC, Schaller D, Ravier F, Golaz O, Jaccoud S, Belet M, Wilkins MR, James R, Deshusses J, \& Hochstrasser D (1997) Translationally controlled tumor protein: a protein identified in several nontumoral cells including erythrocytes. Electrophoresis 18(1):150-155.

64. Arcuri F, Papa S, Carducci A, Romagnoli R, Liberatori S, Riparbelli MG, Sanchez JC, Tosi P, \& del Vecchio MT (2004) Translationally controlled tumor protein (TCTP) in the human prostate and prostate cancer cells: expression, distribution, and calcium binding activity. The Prostate 60(2):130-140.

65. Mulenga A \& Azad AF (2005) The molecular and biological analysis of ixodid ticks histamine release factors. Experimental \& applied acarology 37(3-4):215-229.

66. Bangrak P, Graidist P, Chotigeat W, \& Phongdara A (2004) Molecular cloning and expression of a mammalian homologue of a translationally controlled tumor protein (TCTP) gene from Penaeus monodon shrimp. Journal of biotechnology 108(3):219226.

67. Graidist P, Yazawa M, Tonganunt M, Nakatomi A, Lin CC, Chang JY, Phongdara A, $\&$ Fujise $\mathrm{K}$ (2007) Fortilin binds $\mathrm{Ca} 2+$ and blocks $\mathrm{Ca} 2+$-dependent apoptosis in vivo. The Biochemical journal 408(2):181-191.

68. Lucas AT, Fu X, Liu J, Brannon MK, Yang J, Capelluto DG, \& Finkielstein CV (2014) Ligand binding reveals a role for heme in translationally-controlled tumor protein dimerization. PloS one 9(11):e112823.

69. $\mathrm{Xu} \mathrm{A}$, Bellamy AR, \& Taylor JA (1999) Expression of translationally controlled tumour protein is regulated by calcium at both the transcriptional and posttranscriptional level. The Biochemical journal 342:683-689.

70. Tuynder M, Fiucci G, Prieur S, Lespagnol A, Geant A, Beaucourt S, Duflaut D, Besse S, Susini L, Cavarelli J, Moras D, Amson R, \& Telerman A (2004) Translationally 
controlled tumor protein is a target of tumor reversion. Proceedings of the National Academy of Sciences of the United States of America 101(43):15364-15369.

71. Zhang X (2014) Etude de complexes protéine-protéine impliquant la chaperone de bas poids moléculaire HSP27: Implications dans le cancer de la prostate. $\mathrm{PhD}$ Thesis $(\mathrm{PhD}$ Thesis, Aix-Marseille Université).

72. Seo EJ \& Efferth $\mathrm{T}$ (2016) Interaction of antihistaminic drugs with human translationally controlled tumor protein (TCTP) as novel approach for differentiation therapy. Oncotarget 7(13):16818-16839.

73. Kim M, Chung J, Lee C, Jung J, Kwon Y, \& Lee K (2011) A peptide binding to dimerized translationally controlled tumor protein modulates allergic reactions. Journal of molecular medicine 89(6):603-610.

74. Kadioglu O \& Efferth T (2016) Peptide aptamer identified by molecular docking targeting translationally controlled tumor protein in leukemia cells. Invest New Drugs.

75. Krishna S, Uhlemann AC, \& Haynes RK (2004) Artemisinins: mechanisms of action and potential for resistance. Drug resistance updates : reviews and commentaries in antimicrobial and anticancer chemotherapy 7(4-5):233-244.

76. Bhisutthibhan J \& Meshnick SR (2001) Immunoprecipitation of $[(3) \mathrm{H}]$ dihydroartemisinin translationally controlled tumor protein (TCTP) adducts from Plasmodium falciparum-infected erythrocytes by using anti-TCTP antibodies. Antimicrobial agents and chemotherapy 45(8):2397-2399.

77. Bhisutthibhan J, Philbert MA, Fujioka H, Aikawa M, \& Meshnick SR (1999) The Plasmodium falciparum translationally controlled tumor protein: subcellular localization and calcium binding. European journal of cell biology 78(9):665-670.

78. Bhisutthibhan J, Pan XQ, Hossler PA, Walker DJ, Yowell CA, Carlton J, Dame JB, \& Meshnick SR (1998) The Plasmodium falciparum translationally controlled tumor protein homolog and its reaction with the antimalarial drug artemisinin. The Journal of biological chemistry 273(26):16192-16198.

79. Zhou Y, Li W, \& Xiao Y (2016) Profiling of Multiple Targets of Artemisinin Activated by Hemin in Cancer Cell Proteome. ACS Chem Biol 11(4):882-888.

80. Li W, Zhou Y, Tang G, \& Xiao Y (2016) Characterization of the Artemisinin Binding Site for Translationally Controlled Tumor Protein (TCTP) by Bioorthogonal Click Chemistry. Bioconjugate chemistry 27(12):2828-2833.

81. Slomianny C (1990) Three-dimensional reconstruction of the feeding process of the malaria parasite. Blood Cells 16(2-3):369-378.

82. Abu Bakar N, Klonis N, Hanssen E, Chan C, \& Tilley L (2010) Digestive-vacuole genesis and endocytic processes in the early intraerythrocytic stages of Plasmodium falciparum. J Cell Sci 123(Pt 3):441-450.

83. Klonis N, Crespo-Ortiz MP, Bottova I, Abu-Bakar N, Kenny S, Rosenthal PJ, \& Tilley L (2011) Artemisinin activity against Plasmodium falciparum requires hemoglobin uptake and digestion. Proc Natl Acad Sci U S A 108(28):11405-11410.

84. Crespo-Ortiz MP \& Wei MQ (2012) Antitumor activity of artemisinin and its derivatives: from a well-known antimalarial agent to a potential anticancer drug. $J$ Biomed Biotechnol 2012:247597.

85. Krishna S, Bustamante L, Haynes R, \& Staines H (2008) Artemisinins: their growing importance in medicine. Trends Pharmacol Sci. 29(10):520-527.

86. Fujita T, Felix K, Pinkaew D, Hutadilok-Towatana N, Liu Z, \& Fujise K (2008) Human fortilin is a molecular target of dihydroartemisinin. FEBS letters 582(7):10551060 .

87. O'Neill PM, Barton VE, \& Ward SA (2010) The molecular mechanism of action of artemisinin--the debate continues. Molecules 15(3):1705-1721. 
88. Koziol MJ, Garrett N, \& Gurdon JB (2007) Tpt1 activates transcription of oct4 and nanog in transplanted somatic nuclei. Curr Biol 17(9):801-807.

89. Cheng X, Li J, Deng J, Li Z, Meng S, \& Wang H (2012) Translationally controlled tumor protein (TCTP) downregulates Oct4 expression in mouse pluripotent cells. $B M B$ reports $45(1): 20-25$.

90. Johansson H \& Simonsson S (2010) Core transcription factors, Oct4, Sox2 and Nanog, individually form complexes with nucleophosmin (Npm1) to control embryonic stem (ES) cell fate determination. Aging (Albany NY) 2(11):815-822.

91. Castello A, Fischer B, Eichelbaum K, Horos R, Beckmann BM, Strein C, Davey NE, Humphreys DT, Preiss T, Steinmetz LM, Krijgsveld J, \& Hentze MW (2012) Insights into RNA biology from an atlas of mammalian mRNA-binding proteins. Cell 149(6):1393-1406.

92. Wang F, Hu C, Hua X, Song L, \& Xia Q (2013) Translationally controlled tumor protein, a dual functional protein involved in the immune response of the silkworm, Bombyx mori. PloS one 8(7):e69284.

93. Le TP, Vuong LT, Kim AR, Hsu YC, \& Choi KW (2016) 14-3-3 proteins regulate Tctp-Rheb interaction for organ growth in Drosophila. Nature communications 7:11501.

94. Jung J, Kim HY, Maeng J, Kim M, Shin DH, \& Lee K (2014) Interaction of translationally controlled tumor protein with Apaf-1 is involved in the development of chemoresistance in HeLa cells. BMC cancer 14:165.

95. Li S, Chen M, Xiong Q, Zhang J, Cui Z, \& Ge F (2016) Characterization of the translationally controlled tumor protein (TCTP) interactome reveals novel binding partners in human cancer cells. Journal of proteome research 15:3741-3751.

96. Katsogiannou M, Andrieu C, Baylot V, Baudot A, Dusetti NJ, Gayet O, Finetti P, Garrido C, Birnbaum D, Bertucci F, Brun C, \& Rocchi P (2014) The functional landscape of Hsp27 reveals new cellular processes such as DNA repair and alternative splicing and proposes novel anticancer targets. Molecular \& cellular proteomics : MCP 13(12):3585-3601.

97. Chattopadhyay A, Pinkaew D, Doan HQ, Jacob RB, Verma SK, Friedman H, Peterson AC, Kuyumcu-Martinez MN, McDougal OM, \& Fujise K (2016) Fortilin potentiates the peroxidase activity of Peroxiredoxin-1 and protects against alcohol-induced liver damage in mice. Scientific reports 6:18701.

98. Chen K, Huang C, Yuan J, Cheng H, \& Zhou R (2014) Long-term artificial selection reveals a role of TCTP in autophagy in mammalian cells. Molecular biology and evolution 31(8):2194-2211.

99. Johansson H, Svensson F, Runnberg R, Simonsson T, \& Simonsson S (2010) Phosphorylated nucleolin interacts with translationally controlled tumor protein during mitosis and with Oct4 during interphase in ES cells. PloS one 5(10):e13678.

100. Kashiwakura JC, Ando T, Matsumoto K, Kimura M, Kitaura J, Matho MH, Zajonc DM, Ozeki T, Ra C, MacDonald SM, Siraganian RP, Broide DH, Kawakami Y, \& Kawakami T (2012) Histamine-releasing factor has a proinflammatory role in mouse models of asthma and allergy. The Journal of clinical investigation 122(1):218-228.

101. Rid R, Onder K, Trost A, Bauer J, Hintner H, Ritter M, Jakab M, Costa I, Reischl W, Richter K, MacDonald S, Jendrach M, Bereiter-Hahn J, \& Breitenbach M (2010) $\mathrm{H} 2 \mathrm{O} 2$-dependent translocation of TCTP into the nucleus enables its interaction with VDR in human keratinocytes: TCTP as a further module in calcitriol signalling. The Journal of steroid biochemistry and molecular biology 118(1-2):29-40.

102. Gachet Y, Tournier S, Lee M, Lazaris-Karatzas A, Poulton T, \& Bommer UA (1999) The growth-related, translationally controlled protein P23 has properties of a tubulin 
binding protein and associates transiently with microtubules during the cell cycle. $J$ Cell Sci 112 ( Pt 8):1257-1271.

103. Rho SB, Lee JH, Park MS, Byun HJ, Kang S, Seo SS, Kim JY, \& Park SY (2011) Anti-apoptotic protein TCTP controls the stability of the tumor suppressor p53. FEBS letters 585(1):29-35.

104. Funston G, Goh W, Wei SJ, Tng QS, Brown C, Jiah Tong L, Verma C, Lane D, \& Ghadessy F (2012) Binding of Translationally Controlled Tumour Protein to the Nterminal domain of HDM2 is inhibited by nutlin-3. PloS one 7(8):e42642.

105. Yoon T, Jung J, Kim M, Lee KM, Choi EC, \& Lee K (2000) Identification of the selfinteraction of rat TCTP/IgE-dependent histamine-releasing factor using yeast twohybrid system. Arch Biochem Biophys 384(2):379-382.

106. Liu H, Peng HW, Cheng YS, Yuan HS, \& Yang-Yen HF (2005) Stabilization and enhancement of the antiapoptotic activity of mcl-1 by TCTP. Molecular and cellular biology 25(8):3117-3126.

107. Jaglarz MK, Bazile F, Laskowska K, Polanski Z, Chesnel F, Borsuk E, Kloc M, \& Kubiak JZ (2012) Association of TCTP with centrosome and microtubules. Biochemistry research international 2012:541906.

108. Jeon HJ, You SY, Park YS, Chang JW, Kim JS, \& Oh JS (2016) TCTP regulates spindle microtubule dynamics by stabilizing polar microtubules during mouse oocyte meiosis. Biochimica et biophysica acta 1863(4):630-637.

109. Burgess A, Labbe JC, Vigneron S, Bonneaud N, Strub JM, Van Dorsselaer A, Lorca T, \& Castro A (2008) Chfr interacts and colocalizes with TCTP to the mitotic spindle. Oncogene 27(42):5554-5566.

110. Johansson H, Vizlin-Hodzic D, Simonsson T, \& Simonsson S (2010) Translationally controlled tumor protein interacts with nucleophosmin during mitosis in ES cells. Cell cycle (Georgetown, Tex.) 9(11):2160-2169.

111. Choi KW \& Hsu YC (2007) To cease or to proliferate: new insights into TCTP function from a Drosophila study. Cell adhesion \& migration 1(3):129-130.

112. Chen Y, Fujita T, Zhang D, Doan H, Pinkaew D, Liu Z, Wu J, Koide Y, Chiu A, Lin CC, Chang JY, Ruan KH, \& Fujise K (2011) Physical and functional antagonism between tumor suppressor protein p53 and fortilin, an anti-apoptotic protein. The Journal of biological chemistry 286(37):32575-32585.

113. Zhang D, Li F, Weidner D, Mnjoyan ZH, \& Fujise K (2002) Physical and functional interaction between myeloid cell leukemia 1 protein (MCL1) and Fortilin. The potential role of MCL1 as a fortilin chaperone. The Journal of biological chemistry 277(40):37430-37438.

114. Lee JH, Rho SB, Park SY, \& Chun T (2008) Interaction between fortilin and transforming growth factor-beta stimulated clone-22 (TSC-22) prevents apoptosis via the destabilization of TSC-22. FEBS letters 582(8):1210-1218.

115. Leclercq TM, Moretti PA, \& Pitson SM (2011) Guanine nucleotides regulate sphingosine kinase 1 activation by eukaryotic elongation factor $1 \mathrm{~A}$ and provide a mechanism for eEF1A-associated oncogenesis. Oncogene 30(3):372-378.

116. Langdon JM, Vonakis BM, \& MacDonald SM (2004) Identification of the interaction between the human recombinant histamine releasing factor/translationally controlled tumor protein and elongation factor-1 delta (also known as eElongation factor-1B beta). Biochimica et biophysica acta 1688(3):232-236.

117. Fleischer TC, Weaver CM, McAfee KJ, Jennings JL, \& Link AJ (2006) Systematic identification and functional screens of uncharacterized proteins associated with eukaryotic ribosomal complexes. Genes Dev 20(10):1294-1307. 
118. Hong ST \& Choi KW (2013) TCTP directly regulates ATM activity to control genome stability and organ development in Drosophila melanogaster. Nature communications 4:2986.

119. Jung J, Kim M, Kim MJ, Kim J, Moon J, Lim JS, Kim M, \& Lee K (2004) Translationally controlled tumor protein interacts with the third cytoplasmic domain of $\mathrm{Na}, \mathrm{K}-\mathrm{ATPase}$ alpha subunit and inhibits the pump activity in HeLa cells. The Journal of biological chemistry 279(48):49868-49875.

120. Yoon T, Kim M, \& Lee K (2006) Inhibition of Na,K-ATPase-suppressive activity of translationally controlled tumor protein by sorting nexin 6. FEBS letters 580(14):3558-3564.

121. Tonganunt M, Nupan B, Saengsakda M, Suklour S, Wanna W, Senapin S, Chotigeat W, \& Phongdara A (2008) The role of Pm-fortilin in protecting shrimp from white spot syndrome virus (WSSV) infection. Fish \& shellfish immunology 25(5):633-637.

122. Panrat T, Sinthujaroen P, Nupan B, Wanna W, Tammi MT, \& Phongdara A (2012) Characterization of a novel binding protein for Fortilin/TCTP--component of a defense mechanism against viral infection in Penaeus monodon. PloS one 7(3):e33291.

123. Chen K, Chen S, Huang C, Cheng H, \& Zhou R (2013) TCTP increases stability of hypoxia-inducible factor lalpha by interaction with and degradation of the tumour suppressor VHL. Biology of the cell / under the auspices of the European Cell Biology Organization 105(5):208-218.

124. Kawakami T, Kashiwakura J, \& Kawakami Y (2014) Histamine-releasing factor and immunoglobulins in asthma and allergy. Allergy Asthma Immunol Res 6(1):6-12.

125. Telerman A, Amson R, Cans C, Nancy-Portebois V, \& Passer BJ (2006) (06/29/2006 ).

126. Niikura M, Liu HC, Dodgson JB, \& Cheng HH (2004) A comprehensive screen for chicken proteins that interact with proteins unique to virulent strains of Marek's disease virus. Poult Sci 83(7):1117-1123.

127. Gu X, Yao L, Ma G, Cui L, Li Y, Liang W, Zhao B, \& Li K (2014) TCTP promotes glioma cell proliferation in vitro and in vivo via enhanced beta-catenin/TCF-4 transcription. Neuro-oncology 16(2):217-227.

128. Baylot V, Katsogiannou M, Andrieu C, Taieb D, Acunzo J, Giusiano S, Fazli L, Gleave M, Garrido C, \& Rocchi P (2012) Targeting TCTP as a new therapeutic strategy in castration-resistant prostate cancer. Molecular therapy : the journal of the American Society of Gene Therapy 20(12):2244-2256. 